\title{
Characterization of Olfactory Stem Cells
}

\author{
Andrew Wetzig, ${ }^{1}$ Alan Mackay-Sim, and Wayne Murrell \\ Eskitis Institute for Cell and Molecular Therapies, National Centre for Adult Stem Cell Research, \\ Griffith University, Nathan, Queensland, Australia
}

\begin{abstract}
There is worldwide enthusiasm for the prospect of some kind of cellular transplant therapy for repair of failing organs. The olfactory mucosa of a patient's nose is easily biopsied to provide a ready source of multipotent cells. In this article we address practical issues pertinent to using olfactory neural stem cells for tissue repair. These cells are emerging as potentially most significant candidates for human tissue repair strategies. Previously we have shown that stem cells from olfactory mucosa are multipotent. As well, we have recently published three potential clinical applications. Their expression of dopaminergic markers in vitro and in a Parkinson's rat transplant model has been demonstrated. Their conversion to chondrogenic phenotype in vitro and in vivo has also been described, as has their transplant into a rat model of cardiac infarction. Here we examine in detail the biology of the olfactory neural stem cell using the rat as our animal model cell source. We establish its presence by examining self-renewal capacity and for phenotypic acquisition in inductive circumstances. We determine its frequency within the cell population and show that our culture system selects for this putative stem cell. Our studies demonstrate that adult olfactory stem cells, when transplanted into an environmental niche different from that of their origin, are able to demonstrate multipotency by acquiring the phenotype of the resident cells. We investigate how immediate the instruction need be. We test the hypothesis that olfactory neurospheres contain stem cells whose capacity for differentiation is triggered by signals of the immediate environmental niche. Significantly, of importance to any tissue regeneration endeavor, stem cell numbers were shown to be enriched by our culture methods. This was confirmed whether measured by sphere-forming capacity or differentiation response rate.
\end{abstract}

Key words: Olfactory; Stem cell; Rat; Neurosphere; Clonal cell type; Cell differentiation; Multipotent

\section{INTRODUCTION}

There is worldwide enthusiasm for the prospect of some kind of cellular transplant therapy for repair of failing organs $(7,82,84)$. Recently we have demonstrated the prospect of autologous tissue repair for Parkinson's disease (69), herniated disc (68), and heart attack (61). Using a patient's own neural stem cells derived by simple nasal biopsy and expanded in vitro to supply cellular substrate for the assisted healing of damaged or diseased tissue is an attractive scenario.

\section{Potential of Olfactory-Derived Stem Cells}

The olfactory epithelium must undergo vigorous neurogenesis and continual replacement of sensory neurons throughout adult life $(10,29,57)$. We work on the potential use of the putative olfactory stem cell in tissue transplant therapies and have demonstrated a broad multipotency of these cells (67). They reconstituted the hematopoietic sys- tem of irradiated rats (67) and made nonneural cell types in vitro in transwell coculture experiments (67). They are an attractive source of autologous stem cells because of the ease with which they can be obtained by simple biopsy of as little as $10 \mathrm{~mm}^{3}$ of tissue from a patient's nose (67).

Recently their expression of dopaminergic markers in various growth factor conditions and on protein attachment substrates has been demonstrated (69) as has their conversion to chondrogenic phenotype in vitro and in vivo (68). In a rat model of cardiac infarction transplantation of neurosphere-derived cells from adult rat olfactory mucosa restored heart rate, with other trends towards improvement in other measures of ventricular function indicated (61). Importantly, donor-derived cells engrafted in the transplanted cardiac ventricle and expressed cardiac contractile proteins.

The identity of the olfactory stem cell in vivo has been long debated $(13,17,36,49)$. Importantly, it is not

Received June 7, 2010; final acceptance January 10, 2011. Online prepub date: April 29, 2011.

${ }^{1}$ Current address: King Faisal Specialist Hospital and Research Centre, P.O Box 3354 MBC 03, Riyadh 11211, Kingdom of Saudi Arabia.

Address correspondence to Wayne Murrell at his current address: Vilhelm Magnus Center, Institute for Surgical Research, Rikshospital, University of Oslo, Norway 0027. Tel: 47 23071405; Fax: 47 23071397; E-mail: Wayne.Murrell@rr-research.no 
to be confused with the olfactory ensheathing cell (a type of glial cell that ensheathes olfactory neurons), which has been applied to a number of spinal repair protocols $(5,51,54-56)$. For the purposes of this article we define the olfactory stem cell pragmatically as the neurosphere-forming cell in olfactory mucosal cultures. These cells have recently been shown useful for studying disease of neurogenic origin $(60,87)$. We examine basic aspects of the biology of the olfactory neural stem cell with the view to fully exploit its potential in cell transplant therapy scenarios. We examine its potential for self-renewal and for phenotypic expression in various inductive circumstances. We determine its frequency within the cell population and establish a culture system for selecting this putative stem cell.

Many studies have demonstrated that adult stem cells, when transplanted into an environmental niche different from that of their origin, are able to acquire the phenotype of the resident cells $(6,9,20,22,37,39,48,59$, $63,73)$. How immediate need the instruction be? Here we test the hypothesis that rat olfactory neurospheres contain multipotent stem cells whose capacity for differentiation is triggered by signals of the immediate cellular environment. The relative importance of cell-cell contact or soluble factors was examined by direct contact cocultures, and transwell cocultures, in which cells were physically separated but shared a common medium.

\section{MATERIALS AND METHODS}

\section{Animals}

Female adult (6 weeks old) Sprague-Dawley rats were obtained from the Royal Brisbane Hospital Animal House (Queensland, Australia). Animals were killed by lethal injection (pentobarbitone sodium) in accordance with the guidelines of Griffith University Animal Ethics Committee and the National Health and Medical Research Council of Australia.

\section{Olfactory Mucosa Cultures}

Rat olfactory epithelium (24) and lamina propria (5) was prepared as previously described. The olfactory mucosa was dissected free from the nasal cavity and washed twice in Hanks balanced salt solution (HBSS). The mucosa was incubated for $45 \mathrm{~min}$ at $37^{\circ} \mathrm{C}$ in 2.4 $\mathrm{U} / \mathrm{ml}$ dispase II solution. The olfactory epithelium was then carefully separated from the underlying lamina propria using a microspatula. It was removed and washed in $\mathrm{HBSS}$, then incubated at $37^{\circ} \mathrm{C}$ for $10 \mathrm{~min}$ in $0.25 \%$ collagenase IA solution in DMEM-ITS [Dulbecco's modified Eagles medium/Ham's nutrient mixture F-12 (DMEM) supplemented with insulin, transferrin and selenium (ITS), and penicillin and streptomycin]. The tissue was dissociated by gentle trituration and the colla- genase activity stopped by adding HBSS. The dissociated cells were then centrifuged and resuspended in DMEMFCS [DMEM with penicillin and streptomycin, plus $10 \%$ heat-inactivated fetal calf serum (FCS)]. After the removal of the lamina propria the remaining olfactory epithelium was collected in HBSS and gently triturated to separate the cells. The dispersed cells were then centrifuged and resuspended in DMEM-FCS. The lamina propria cells and olfactory epithelium cells were then combined and plated on uncoated plastic dishes.

\section{Defined Serum-Free Sphere-Forming Conditions}

Primary olfactory mucosa cultures were expanded as a monolayer in DMEM-FCS until confluent, usually 8-12 days. Once confluent, the cells were passaged by using a $2: 5$ solution of $0.25 \%$ trypsin, $0.02 \%$ EDTA in $\mathrm{HBSS}$ and incubating at $37^{\circ} \mathrm{C}$ in $5 \% \mathrm{CO}_{2}$ for $10 \mathrm{~min}$, after which DMEM-FCS was added to inhibit the trypsin. The detached cells were collected, centrifuged, and resuspended in DMEM-ITS. Cell counting was carried out in triplicate, using a hemocytometer. Cells were plated in serum-free conditions onto plastic wells that had been coated with poly-L-lysine (PLL; Sigma p6282; $0.85 \mu \mathrm{g} / \mathrm{cm}^{2}$ ) for $3-4 \mathrm{~h}$. For all the sphere formation experiments three wells were established for each condition per experiment and the experiments repeated three times.

For assay of sphere formation, cells were plated at 50,000 cells $/ \mathrm{cm}^{2}$ in DMEM-ITS, DMEM-ITS + $50 \mathrm{ng} /$ $\mathrm{ml}$ epidermal growth factor (EGF), DMEM-ITS + 25 $\mathrm{ng} / \mathrm{ml}$ basic fibroblast growth factor-2 (FGF2), or DMEM-ITS + $50 \mathrm{ng} / \mathrm{ml}$ EGF and $25 \mathrm{ng} / \mathrm{ml} \mathrm{FGF2.} \mathrm{The}$ media was changed every 2 days at which time sphere counts were carried out.

For the cell density assay of sphere formation, cells were plated at 40,000, 50,000, 60,000, 70,000, 80,000, and 90,000 cells/cm² in DMEM-ITS + EGF and FGF2. In order to be classified arbitrarily as a "sphere" an aggregate measured at least $100 \mu \mathrm{m}$ in diameter, and was spherical and optically dense.

\section{Formation of Second/Next Generation Neurospheres}

After neurospheres had formed, the wells were gently washed three to four times with DMEM-ITS to collect floating and loosely attached neurospheres. They were dissociated in dispase $2.4 \mathrm{U} / \mathrm{ml}$ and $10 \mu \mathrm{g} / \mathrm{ml}$ DNase on an orbital shaker at $37^{\circ} \mathrm{C}, 100 \mathrm{rpm}$ for $15 \mathrm{~min}$ after which they were gently triturated 15 times. This procedure was repeated twice. The dissociated neurospheres were washed in HBSS and resuspended in DMEM-FCS and plated onto plastic dishes. In the same way as the primary cultures, the dissociated neurosphere cells were proliferated adherently to confluence in DMEM-FCS. This was called "expansion phase." Expanded first-gener- 
ation neurospheres were passaged as described above, replated onto PLL-coated wells in EGF and FGF2, at $5,000,10,000,20,000,30,000,40,000$, and 50,000 cells/ $\mathrm{cm}^{2}$, and sphere counts and media changes were carried out every 2 days. Similarly, in turn, later generation neurospheres were collected, dissociated, expanded, and then plated at 5,000 to 50,000 cells $/ \mathrm{cm}^{2}$.

Clonal Analysis of Firstand Sixth-Generation Neurospheres

Neurospheres were generated and dissociated as described above; the dissociated cells were labeled with PKH26 red fluorescent cell linker kit, as per instructions, and plated onto wells (96-well plates) coated with collagen IV $\left(5 \mu \mathrm{g} / \mathrm{cm}^{2}\right)$ at a planned density of 0.5 cells/ well in DMEM-FCS. This procedure was aimed at minimizing the number of wells containing more than one cell. After $24 \mathrm{~h}$ wells were examined to confirm which had single cells plated. Single cells were then expanded to confluence and passaged to increase cell numbers. When there were sufficient cells, clones were passaged and plated in sphere forming conditions.

\section{Cytospinning}

Neurospheres were dissociated as previously described and cells were then cytospun at $1100 \mathrm{rpm}$ for 5 min onto SuperFrost Plus microscope slides (MenzelGlaser) using the SIGMA cytology rotor as per manufacturer's instructions at a density of $\sim 10,000$ cells/ slide.

\section{Immunochemistry}

Cells were fixed in $4 \%$ paraformaldehyde for $7 \mathrm{~min}$, washed, and stored in phosphate-buffered saline (PBS) + $0.1 \%$ sodium azide. Wells were blocked in $10 \%$ goat serum, $2 \%$ bovine serum albumin (BSA), $0.1 \%$ Triton $\mathrm{X}-100$ in PBS for $1 \mathrm{~h}$ at room temperature. Primary antibodies were: rabbit polyclonals - $\beta$-tubulin-III (Covance, $0.33 \mu \mathrm{g} / \mathrm{ml}$ ), glial fibrillary acidic protein (GFAP) (Dakocytomation, $6 \mu \mathrm{g} / \mathrm{ml}$ ), $\beta$-1-integrin (Santa Cruz Biotechnology, $4 \mu \mathrm{g} / \mathrm{ml}$ ), tyrosine kinase receptor-1 (TrkA) (Santa Cruz Biotechnology, $1 \mu \mathrm{g} / \mathrm{ml}$ ), tyrosine kinase receptor-2 (TrkB) (Santa Cruz Biotechnology, $1 \mu \mathrm{g} / \mathrm{ml}$ ), tyrosine kinase receptor-3 (TrkC) (Santa Cruz Biotechnology, $1 \mu \mathrm{g} / \mathrm{ml}$ ), hairy enhancer of split-5 (Hes5) (Chemicon, $10 \mu \mathrm{g} / \mathrm{ml}$ ), and hairy enhancer of split-1 (Hes1) (Chemicon, $10 \mu \mathrm{g} / \mathrm{ml}$ ); mouse monoclonalsCD90 (Thy1) (Serotec, $10 \mu \mathrm{g} / \mathrm{ml}$ ), CD117 (C-Kit) (Zymed Laboratories Inc., $5 \mu \mathrm{g} / \mathrm{ml}$ ), nestin (Chemicon, $5.2 \mu \mathrm{g} / \mathrm{ml}$ ), neurofilament 200 (Sigma, $1.11 \mathrm{mg} / \mathrm{ml}$ ), P75 (low-affinity neurotrophin receptor) (Neubody, $1 \mu \mathrm{g} /$ $\mathrm{ml}$ ), intercellular adhesion molecule-1 (ICAM-1) (PharMingen, $10 \mu \mathrm{g} / \mathrm{ml})$. Primary antibodies were applied in blocking solution for $1 \mathrm{~h}$ at room temperature, after which cells were washed in PBS. Secondary antibodies, goat anti-mouse IgG conjugated with AlexaFluor 594/ 488 and goat anti-rabbit IgG conjugated with AlexaFluor 568/488, were applied at $5 \mu \mathrm{g} / \mathrm{ml}$, for $1 \mathrm{~h}$ at room temperature. The cells were washed in PBS, the nuclei were stained with $1 \mathrm{mM}$ Hoechst 33342 for $10 \mathrm{~min}$, and the cells were washed again.

\section{Phenotype of Neurophere Cells (Expanding in Monolayer)}

Dissociated first-, second-, third-, and sixth-generation sphere cells were plated onto uncoated eight-well chamber slides in DMEM-FCS at a cell density of 5,000 cells/well. The media was changed after 2 days and the cells were fixed the following day (day 3 ).

\section{RNA Isolation and RT-PCR}

Whole first-generation neurospheres were harvested and RNA extracted using the guanidinium thiocyanatephenol-chloroform method (19) followed by DNase I (Ambion) digestion of genomic DNA. Reverse transcription was carried out using SuperScript III (Invitrogen) with oligo(dT12-18) primers (Invitrogen) after which the cDNA was treated with RNase H (Invitrogen). The PCR reaction mix included: $1 \times$ PCR buffer, $1.5 \mathrm{mM}$ $\mathrm{MgCl}_{2}, 0.2 \mathrm{mM}$ DNTPs, $1 \mathrm{U}$ Taq DNA polymerase plus $0.3 \mu \mathrm{M}$ of both forward and reverse primers. Cycle profile was $5 \mathrm{~min}$ at $95^{\circ} \mathrm{C}, 40$ cycles of $30 \mathrm{~s}$ at $95^{\circ} \mathrm{C}, 60 \mathrm{~s}$ at annealing temperature (Table 1), $60 \mathrm{~s}$ at $72^{\circ} \mathrm{C}$ followed by $10 \mathrm{~min}$ at $72^{\circ} \mathrm{C}$.

\section{Establishing Skeletal Muscle Cultures}

Skeletal muscle tissues were diced into $200-\mu \mathrm{m}^{2}$ fragments using a McIlwain tissue chopper. The tissue pieces were collected in $10 \mathrm{ml}$ of HBSS in a 50-ml tube and centrifuged for $5 \mathrm{~min}$ at $300 \times \mathrm{g}$. The tissue pieces were disaggregated by resuspending in $6 \mathrm{ml}$ of a $0.042 \%$ trypsin and $0.25 \mathrm{mg} / \mathrm{ml}$ collagenase IA solution in HBSS and incubating in an orbital shaker at $37^{\circ} \mathrm{C}, 110$ $\mathrm{rpm}$, for $30 \mathrm{~min}$. The tissues were triturated vigorously prior to deactivating the trypsin. Cells were resuspended in HBSS and the larger tissue pieces allowed to settle for a few minutes. The supernatant was collected and passed through a $40-\mu \mathrm{m}$ filter. Tissue pieces were subjected to this treatment several times.

The dissociated skeletal muscle cells were then collected by centrifugation and plated in DMEM-FCS onto uncoated plastic flasks for $2 \mathrm{~h}$ to allow fibroblasts to attach. The unattached cells were then collected and plated onto uncoated glass eight-well chamber slides at a cell density of 2,000 cells/well $\left(2,860\right.$ cells $\left./ \mathrm{cm}^{2}\right)$.

\section{T3-L1 Differentiation}

Dexamethasone (DEX), isobutyl-1-methyl-xanthine (IBMX), biotin, insulin, and oil red $\mathrm{O}$ were purchased 
Table 1. Conditions for PCR Reactions, Primer Sequences, and PCR Products for Various Genes

\begin{tabular}{|c|c|c|c|c|}
\hline Gene & Sequence & $\begin{array}{l}\text { Annealing } \\
\text { Temp. }\end{array}$ & Product & $\begin{array}{l}\text { Accession } \\
\text { No. }\end{array}$ \\
\hline Nestin & 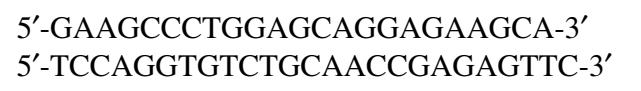 & 62 & 159 & NM_012987 \\
\hline Hes1 & $\begin{array}{l}5^{\prime} \text {-CCAGACTAAAACCAAGACGGGG-3' } \\
5^{\prime} \text {-AGCCAATGGGAGGAAGAGACAC-3' }\end{array}$ & 59 & 208 & NM_024360 \\
\hline Hes5 & $\begin{array}{l}\text { 5'-CTCAGTCCCAAGGAGAAAAATCG-3' } \\
\text { 5'-GGCTTTGCTGTGCTTCAGGTAG-3' }^{\prime}\end{array}$ & 59 & 192 & NM_024383 \\
\hline Notch-1 & $\begin{array}{l}\text { 5'-TCTGGACACAAGATCGATGGTACG-3' } \\
\text { 5'-CGTTGACACAAGGGTTGGACTC-3' }^{\prime}\end{array}$ & 60 & 328 & XM_342392 \\
\hline CD90 & $\begin{array}{l}\text { 5'-AACACCAACTTGCCCATCCAG-3' } \\
\text { 5'-CTTATGCCACCACACTTGACCA-3' }^{\prime}\end{array}$ & 57 & 275 & NM_012673 \\
\hline TrkA & 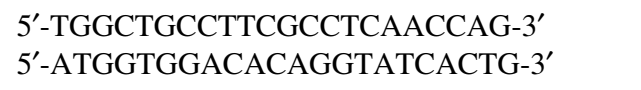 & 61 & 484 & M85214 \\
\hline TrkB & $\begin{array}{l}5^{\prime} \text {-CAAGCCGGACACATTTGTTCAGC-3' } \\
5^{\prime} \text {-AGTGTTGGGATGCCAGGTAGACCAT-3' }\end{array}$ & 60 & 443 & NM_012731 \\
\hline TrkC & $\begin{array}{l}\text { 5'-AAGCAACCATGGTTCCAGCTCTCT-3' } \\
5^{\prime} \text {-GTATAAACGCTTGGCCACCAGTCAC-3' }\end{array}$ & 60 & 246 & NM_019248 \\
\hline P75 & $\begin{array}{l}\text { 5'-TGCTGATTCTAGGGGTGTCCTC-3' } \\
\text { 5'-GTGGTTGGCTTCGTCTGAGTATGTG-3' }^{\prime}\end{array}$ & 60 & 428 & NM_012610 \\
\hline Lif-r & $\begin{array}{l}\text { 5'-CAGTGGCTGTGGCTGTCATTGTTG-3' } \\
\text { 5'-CTCTGCTTTGGCTTGTGGCTGATAC-3' }^{\prime}\end{array}$ & 59 & 437 & NM_031048 \\
\hline CD117 & 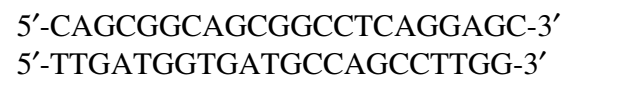 & 59 & 315 & D12524 \\
\hline Oct- 4 & $\begin{array}{l}\text { 5'-GGCGTTCTCTTTGCAAAGGTGTTC-3' } \\
\text { 5'-CTCGAACCACATCCTTCTCT-3' }\end{array}$ & 62 & 312 & NM_001009178 \\
\hline Pax-6 & $\begin{array}{l}\text { 5'-GGAGTGAATCAGCTTGGTGGT-3' } \\
\text { 5'-ATCTGTCTCGGATTTCCCAAGC-3' }^{\prime}\end{array}$ & 57 & 298 & NM_013001 \\
\hline ICAM-1 (CD54) & $\begin{array}{l}\text { 5'-AGGGGACCAAGTAACTGTGAAGTG-3' } \\
\text { 5'-GTCAGATTAGGGGCTGGATTCC-3' }^{\prime}\end{array}$ & 58 & 351 & NM_012967 \\
\hline$\beta$-1-Integrin (CD29) & 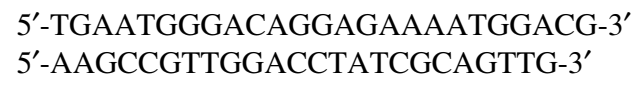 & 58 & 487 & NM_017022 \\
\hline$\beta$-4-Integrin (CD104) & $\begin{array}{l}\text { 5'-CAGGAAGATTCATCCAACATCGTG-3' }^{\prime} \\
\text { 5'-CATCGGAGAAGGAGGGTTTCAG-3' }^{\prime}\end{array}$ & 59 & 286 & NM_013180 \\
\hline CD133 & $\begin{array}{l}\text { 5'-CCTGGTGGGCTTCTTCTTTTG-3' } \\
\text { 5'-TGCTTTGGGGCTTCAGTCA-3' }^{\prime}\end{array}$ & 57 & 261 & NM_021751 \\
\hline CD135 & $\begin{array}{l}\text { 5'-CCTCAAGTGGGAGTTTCCAAGG-3' } \\
\text { 5'-CCAGCAGGTTCACGATGTTGTC-3' }^{\prime}\end{array}$ & 57 & 236 & XM_221874 \\
\hline Presenilin-1 & $\begin{array}{l}5^{\prime} \text {-ATGGCTGAAGGAGACCCAGAAG-3' } \\
5^{\prime} \text {-CCGTGGCAAAGTAGAAAATGAGC-3' }\end{array}$ & 59 & 460 & NM_019163 \\
\hline
\end{tabular}

Nestin, Hes1 (hairy enhancer of split-1), Hes5 (hairy enhancer of split-5), Notch-1, CD90 (Thy-1), TrkA (tyrosine kinase receptor1), TrkB (tyrosine kinase receptor-2), TrkC (tyrosine kinase receptor-3), P75 (low-affinity neurotrophin receptor), Lif-r (leukemia inhibitory factor receptor), CD117 (c-Kit), Oct-4 (octamer-binding transcription factor 4), Pax-6 (paired box protein-6), ICAM-1 or CD54 (intercellular adhesion molecule-1), $\beta$-1-integrin or CD29, CD133, CD135, and presenilin-1. 
from Sigma (St Louis, MO, USA). Transwell cell culture inserts $\left(0.6 \mathrm{~cm}^{2}\right)$ with a pore diameter of $0.4 \mu \mathrm{m}$ were purchased from Millipore (Billerica, MA, USA). 3T3-L1 cells were a generous donation from Dr. Jon Whitehead and Dr. Louise Hutley (Cell Signalling Group, Department of Diabetes \& Endocrinology, University of Queensland). Nonconfluent (80\%) 3T3-L1 mouse fibroblast preadipocyte cell line cultures were passaged using a $1: 5$ solution of $0.25 \%$ trypsin, $0.02 \%$ EDTA in HBSS and incubated at $37^{\circ} \mathrm{C}$ in $5 \% \mathrm{CO}_{2}$ for 2 $\min$. 3T3-L1 cells were seeded at $\sim 5,000$ cells $/ \mathrm{cm}^{2}$ onto plastic flasks and allowed to proliferate until 2 or 3 days postconfluent in DMEM-FCS. Then medium was changed to differentiation medium: DMEM-FCS with the addition of $0.22 \mu \mathrm{M}$ DEX, $0.1 \mu \mathrm{g} / \mathrm{ml}$ biotin, $2 \mu \mathrm{g} / \mathrm{ml}$ insulin, and $0.5 \mathrm{mM}$ IBMX. The cells were cultured in differentiation medium for 3 days after which the medium was changed to postdifferentiation medium (DMEM-FCS plus $2 \mu \mathrm{g} / \mathrm{ml}$ insulin) and the cells cultured for a further 3 days. The medium was changed to normal DMEMFCS and the cells cultured for a further 6 days.

\section{Green Fluorescent Protein (GFP)-Positive, Dissociated Neurosphere Cells Cocultured With 3T3-L1 Cells}

3T3-L1 cells were passaged onto chamber slides at 7,000 cells $/ \mathrm{cm}^{2}$ without neurosphere cells, or with GFPlabeled neurosphere cells at 100,200 , or 500 cells/well $\left(142\right.$ cells $/ \mathrm{cm}^{2}, 284$ cells $/ \mathrm{cm}^{2}$, and 714 cells $/ \mathrm{cm}^{2}$, respectively). In separate wells control cultures were established with only GFP-labeled neurosphere cells. The control cells were plated at the same cell densities as cocultured wells. Both control and cocultured wells were initially plated in DMEM-FCS until 3 days postconfluent at which time the medium was changed to differentiation medium. The cells were cultured in differentiation medium for 3 days, postdifferentiation medium for 3 days, and finally in normal DMEM-FCS for a further 6 days. Immunocytochemistry for glucose transporter-4 (Glut-4) was carried out after the cells were fixed in $4 \%$ paraformaldehyde. Following Glut-4 staining, lipids were stained using oil red $\mathrm{O}$.

\section{T3-L1 Transwell Induction Assay}

As described above, cell culture inserts were coated with collagen and seeded with 3T3-L1 cells at 25,000 cells $/ \mathrm{cm}^{2}$ in DMEM-FCS. Unlabelled dissociated first-, second-, and sixth-generation neurospheres were plated beneath the inserts at 1,000 cells/well $\left(526 \mathrm{cells} / \mathrm{cm}^{2}\right)$, 2,500 cells/well $\left(1,315\right.$ cells/ $\left.\mathrm{cm}^{2}\right), 5,000$ cells/well $(2,631$ cells $\left./ \mathrm{cm}^{2}\right), 10,000$ cells/well $\left(5,263\right.$ cells $\left./ \mathrm{cm}^{2}\right), 20,000$ cells/well $\left(10,526\right.$ cells/ $\left.\mathrm{cm}^{2}\right)$, and 30,000 cells/well $(15,789$ cells $/ \mathrm{cm}^{2}$ ) in DMEM-FCS. The cells were cultured until the 3T3-L1 cells were 3 days postconfluent at which time the medium was changed to differentiation medium and the cells cultured for 3 days.

After 3 days the inserts were replaced with new collagen-coated inserts that had been seeded with 3T3-L1 cells 3 days after the initial cells were plated. The new postconfluent 3T3-L1 cells, and the dissociated neurosphere cells beneath them, were again cultured in differentiation medium for 3 days. After differentiation the medium was replaced with postdifferentiation medium for 3 days and finally normal DMEM-FCS for a further 6 days. The cells were then fixed in $4 \%$ paraformaldehyde and immunocytochemistry for Glut-4 was carried out followed by oil red $\mathrm{O}$ staining for lipids.

\section{Oil Red O Staining}

Oil red $\mathrm{O}$ stain is a lysochrome (lipid soluble dye) used to detect triglycerides. Oil red $\mathrm{O}(0.74 \mathrm{~g})$ was dissolved in $200 \mathrm{ml}$ of isopropanol and mixed overnight at $4^{\circ} \mathrm{C}$. The filtered "stock" solution was stored at $4^{\circ} \mathrm{C}$. The oil red $\mathrm{O}$ "working" solution was prepared by mixing 3 parts stock to 2 parts HBSS and leaving the solution to stand overnight at $4^{\circ} \mathrm{C}$ followed by a filtration step. Cultured cells were washed in PBS prior to adding the lipid stain for $2 \mathrm{~h}$ at room temperature, after which the wells were washed twice in PBS.

\section{Statistical Methods}

Data were recorded using Microsoft Excel and analyzed using Graphpad Prism software. Cumulative sphere formation numbers were assessed using one-way ANOVA. Phenotype assessments for sphere and "expanded" cultures over generations were analyzed using one-way repeated measures ANOVA. A probability of 0.05 was taken as the minimum significant difference in respect of the mean. Bonferroni post hoc tests were applied to test rejected null hypotheses. Gene expression was compared between sphere and expanded cultures using twotailed $t$-test. Phenotypes of clones (both first generation and sixth generation) were assessed by one-way ANOVA followed by Tukey's Multiple Comparison Test of Pairs. Phenotypes of first-generation clones were compared to phenotypes of sixth-generation clones using two-way ANOVA with Bonferroni posttests. Clones were compared with nonclones for each gene expression level using two-way ANOVA and Bonferroni posttests. Increased sphere-forming capacity between clonal generations was assessed by application of a chi-square test. Increase in adipocyte differentiation was assessed with one-way ANOVA and Bonferroni posttest.

\section{RESULTS}

\section{Growing Olfactory Neurospheres}

Defined Growth Factor Conditions and Optimal FirstGeneration Sphere Formation. Expanded primary olfactory mucosa cultures, plated onto PLL-coated wells, 

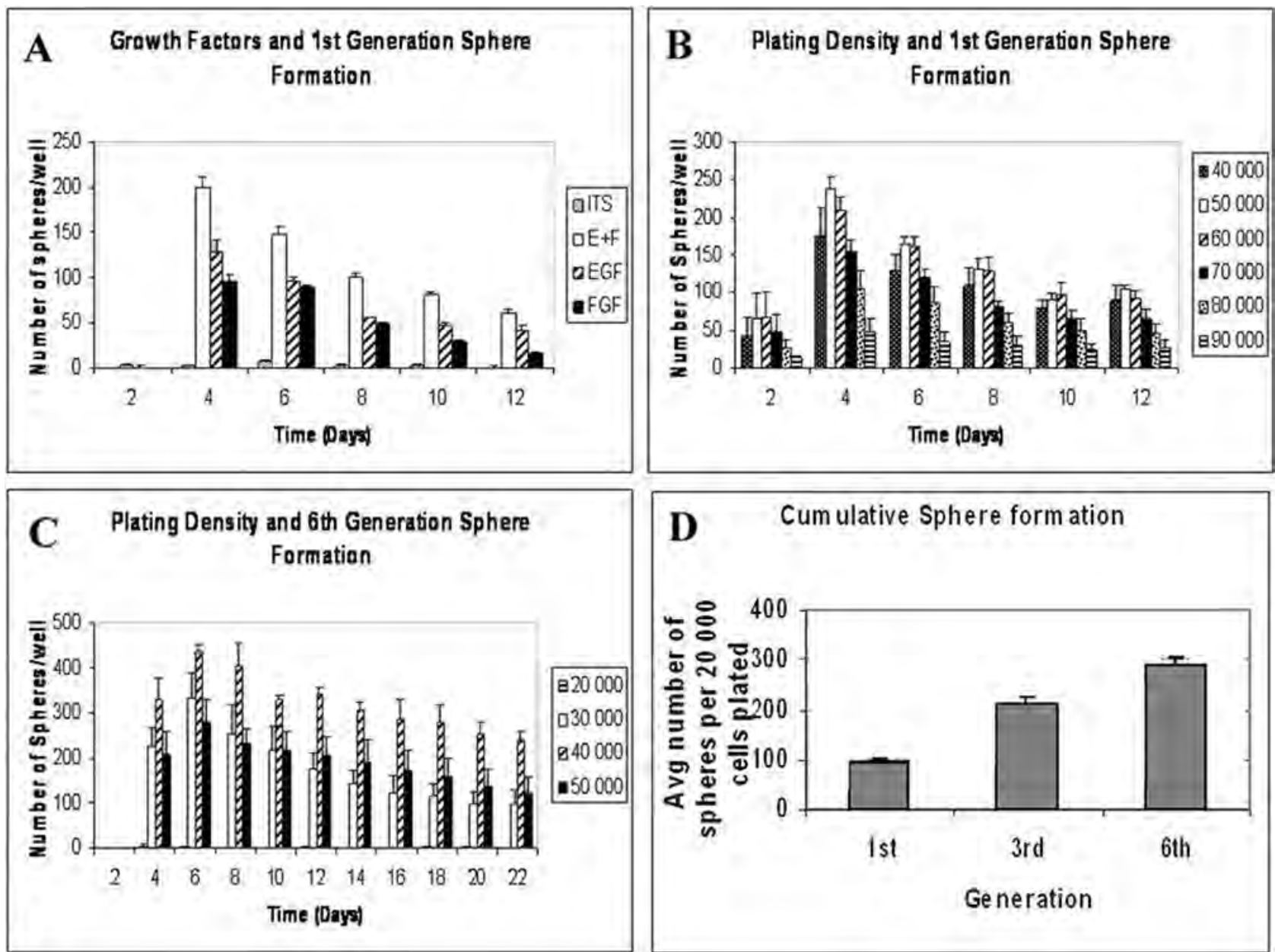

Figure 1. Formation of first- through sixth-generation neurospheres. (A) Formation of neurospheres from expanded primary olfactory mucosa cells in growth factor free medium (ITS), epidermal growth factor (EGF), and basic fibroblast growth factor-2 (FGF2), EGF or FGF2. (B) The formation of neurospheres from "expanded" primary olfactory mucosa cells cultured in EGF and FGF2 at various cell plating densities (from 40,000 to $90,000 \mathrm{cells} / \mathrm{cm}^{2}$ ). (C) The formation of sixth-generation neurospheres from dissociated expanded fifth-generation neurospheres cultured in EGF and FGF2 at various cell plating densities (from 20,000 to 50,000 cell/ $\left.\mathrm{cm}^{2}\right)$. (D) Plot showing a distillation of data detailed above to show the relative enrichment $(p=0.0002)$ of sphere formation as a function of generation of cultures subjected to sphere-forming conditions.

were able to form more neurospheres per well in combination of EGF and FGF2 than either growth factor alone or media without any growth factors (Fig. 1A). In all conditions it was found that there were very few neurospheres formed after 2 days in culture. However, 2 days later the number of neurospheres in growth factorcontaining medium reached its peak (day 4, 200 neurospheres/well) (Fig. 1A). Over the successive 8 days the numbers of neurospheres per well declined steadily as neurospheres detached and were removed.

Cell Density and Formation of First-Generation Neurospheres. When expanded primary olfactory mucosa cultures were plated at 40,000, 50,000, 60,000, 70,000, 80,000 , and 90,000 cells $/ \mathrm{cm}^{2}$ on PLL-coated wells in EGF and FGF2, a concentration curve for optimal sphere formation was observed (Fig. 1B) with the most favorable condition being a plating density of 50,000 cells/ $\mathrm{cm}^{2}$. The maximum number of neurospheres per well was reached after 4 days (237 neurospheres/well); the same decline in neurosphere numbers over the succeeding 8 days was also observed.

Increasing Sphere Formation. Similar analyses were carried out for the formation of third-and sixth-generation neurospheres (Fig. 1C). The number of neurospheres $(\geq 100 \mu \mathrm{m}$ in diameter) produced was calculated across generations as the number of neurospheres arising from 20,000 cells plated. Floating spheres were collected and counted every 2 days; the sum of these was then added to those remaining attached on day 12 ; this sum was then expressed per 20,000 cells originally 
plated. There was a trend towards increased sphere producing cells $(\%)$ with each passing generation: generations $1,0.48 \% ; 3,1.06 \% ; 6,1.45 \%(p=0.0002)$ (Fig. 1D). The pattern of sphere formation for sixth-generation neurospheres is demonstrated in Fig. 2E-H.

RT-PCR Analysis of First-Generation Sphere Phenotype. Whole first-generation neurospheres were harvested, mRNA extracted, RT-PCR carried out, and products sequenced (Fig. 3, Table 2). From this study it was found that the first-generation neurospheres expressed TrkA, TrkC, P75, TrkB, presenilin-1*, leukemia inhibitory factor receptor (Lifr)*, Hes1, ICAM-1, CD90, $\beta$-1integrin, notch-1*, and Hes5. The RT-PCR also showed that the neurospheres were negative for CD117 (c-Kit), octamer-binding transcription factor-4 (Oct-4), paired box protein-6 (Pax-6), CD104 ( $\beta$-4-integrin), CD133, and CD135. Where antibodies were available confirmation of mRNA expression at protein level was confirmed with immunocytochemistry (except those with *; Table 2).

Sphere Phenotype Remained Constant. First-, second-, third-, and sixth-generation neurospheres were dissociated, cytospun, and assessed for their quantitative expression of different markers using immunofluorescence. From these experiments (Figs. 4 and 5A) it was found that the phenotype of the neurospheres remained relatively constant across the generations (repeated mea-
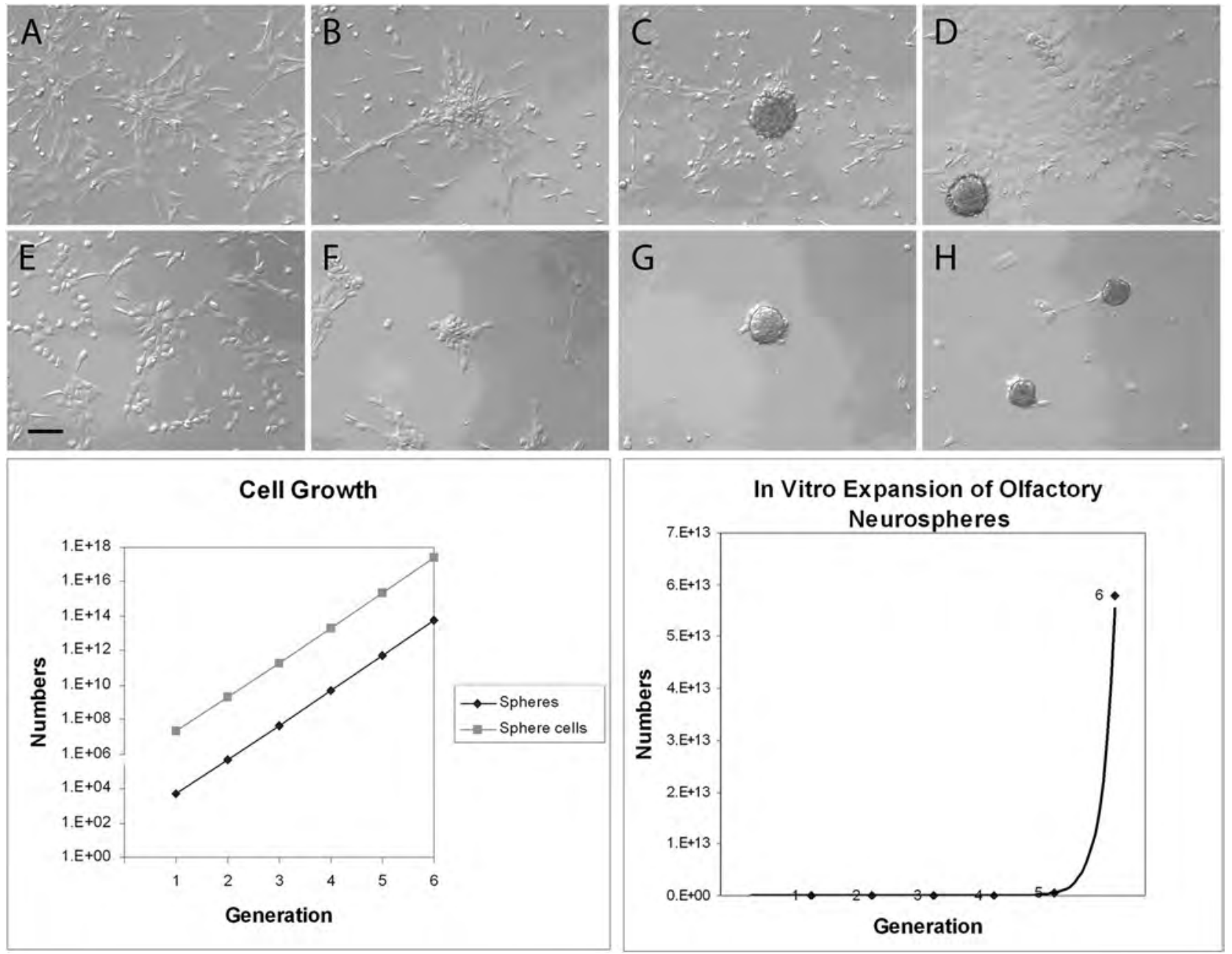

Figure 2. Formation of olfactory neurospheres. (A-D) Formation of first-generation neurospheres in epidermal growth factor (EGF) and basic fibroblast growth factor-2 (FGF2) on plastic wells coated with poly-L-lysine (neurosphere-forming conditions) at day 1 (A), day 2 (B), day 4 (C), and day 15 (D). (E-H) Formation of sixth-generation neurospheres under neurosphere-forming conditions at day $1(\mathrm{E})$, day $2(\mathrm{~F})$, day $4(\mathrm{G})$, and day $15(\mathrm{H})$. Scale bar: $100 \mu \mathrm{m}$. Non-neurosphere-forming cells have proliferated in firstgeneration cultures, while in the sixth-generation cultures there are few cells not participating in neurosphere formation. Bottom panels: Theoretical neurosphere yield over the six generations (if all cells were cultured), with intervening "expansion" cultures (neurospheres $\geq 100 \mu \mathrm{m}$ in diameter) represents a cell yield greater than 35 population doublings since initial cell harvest from the olfactory mucosa. 

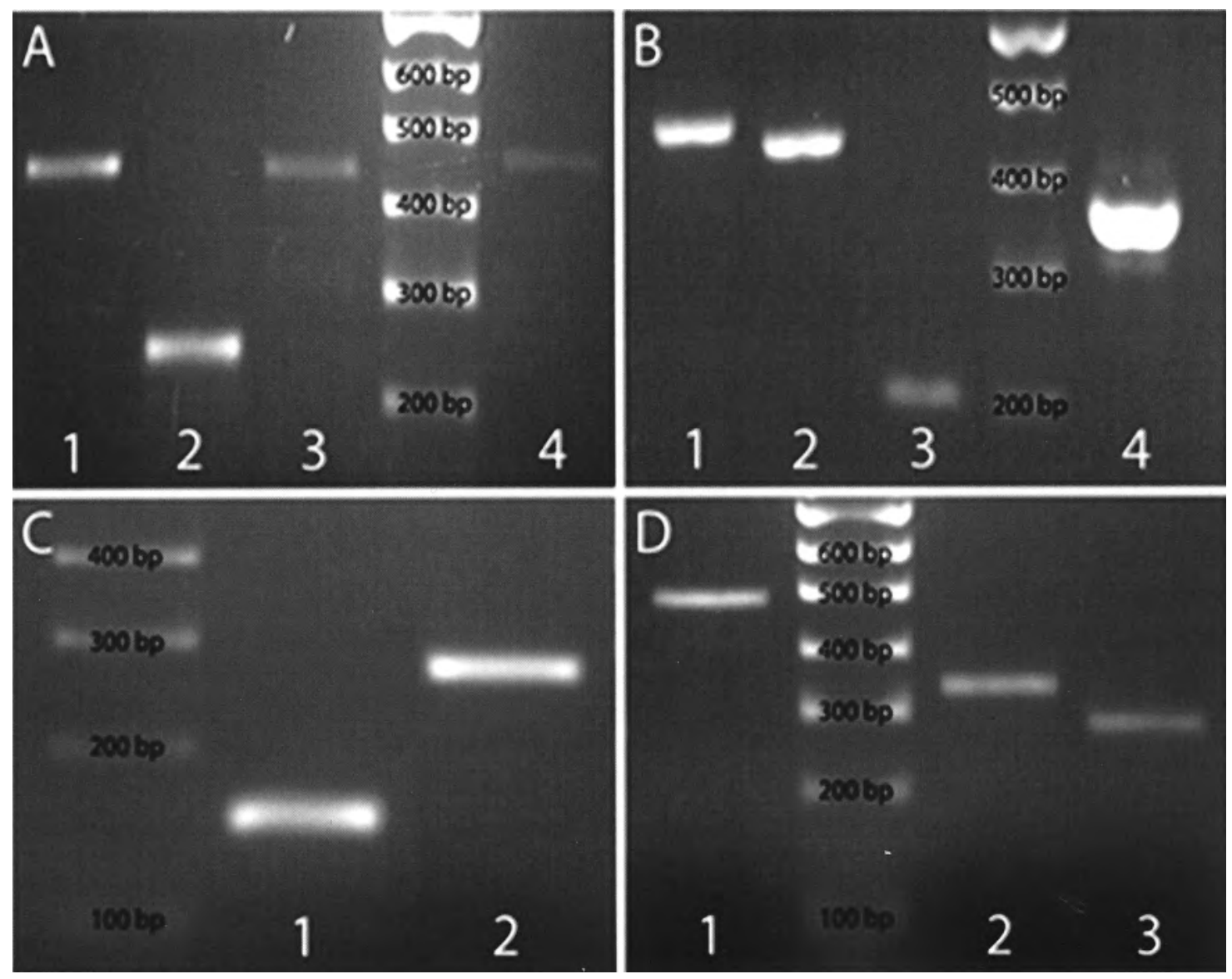

Figure 3. Reverse transcriptase-polymerase chain reaction (RT-PCR) analysis of first-generation spheres. (A) Lane 1: tyrosine kinase receptor-1 (TrkA) (484 bp), lane 2: tyrosine kinase receptor-3 (TrkC) (246 bp), lane 3: low-affinity neurotrophin receptor (P75) (428 bp), and lane 4: tyrosine kinase receptor-2 (TrkB) (443 bp). (B) Lane 1: presenilin-1 (460 bp), lane 2: leukemia inhibitory factor receptor (Lifr) (437 bp), lane 3: hairy enhancer of split-1 (Hes1) (208 bp), and lane 4: intercellular adhesion molecule-1 (ICAM-1 or CD54) (351 bp). (C) Lane 1: nestin (159 bp) and lane 2: Thy-1 (CD90) (275 bp). (D) Lane 1: $\beta$-1-integrin (CD29) (487 bp), lane 2: notch-1 (328 bp), and lane 3: hairy enhancer of split-5 (Hes5) (274 bp).

sures one-way ANOVA for each marker across four generations; means were not significantly different, $p>$ $0.05)$.

Phenotype of Expanding Dissociated Sphere Cells. When dissociated neurospheres were expanded on plastic as a monolayer in serum containing media it was found that there were some significant fluctuations in the expression of some markers (Figs. 4 and 5B). Cells growing out adherently in "expanding" conditions vary significantly more in collective phenotype compared to those that constitute olfactory neurospheres themselves. Phenotype for all markers was not consistent with generation [repeated measures one way ANOVA for each marker across four generations; means were significantly different $(p<0.05)$ : nestin, $p=0.018$; GFAP, $p=0.001$; $\beta$-tubulin III, $p=0.0003 ; \quad \beta$-1-integrin, $p<0.0001$; ICAM-1, $p=0.0075 ; \mathrm{P} 75, p=0.0329]$. When individual gene markers were compared from the two culture methods, three were expressed at a significantly lower level $(p<0.05)$ than in expanded cultures: GFAP $(p<$ $0.0001), \beta$-1-integrin $(p=0.000341)$, and ICAM-1 $(p<$ 0.0001).

Formation of Clonal Neurospheres. Single cells plated clonally under sphere-forming conditions were unable to generate neurospheres. Therefore, experiments were tried in which clonally derived cell populations were then subjected to sphere-forming conditions. Labeled cells from first- and sixth-generation neurospheres were plated at a target density of 0.5 cells/well, and examined after $24 \mathrm{~h}$ for the presence of solitary cells. The phenotypes of dissociated clonal neurospheres from first and sixth generations were assessed for a panel of markers (Fig. 6). These neurospheres varied in proportional expression of phenotype with one first-generation clone 
(11A7) not expressing either neuronal marker. We used one-way ANOVA followed by Tukey's Multiple Comparison test of pairs to discern whether clonal spheres differed in phenotype (Fig. 6). Using this test, means for GFAP $(p<0.0001), \beta$-1-integrin $(p=0.0214)$, Hes 1 $(p=0.0151)$, and Hes5 $(p=0.0106)$ differed significantly in expression. We used two-way ANOVA and Bonferroni posttests to look for differences between clones of the two different generations. Using this test generation 1 differed in phenotype from generation 6 for the markers: nestin $(p=0.018)$; GFAP $(p=0.0089)$; $\beta$ 1-integrin $(p=0.0244)$, and Hes5 $(p=0.0016)$.

Next it seemed relevant to ascertain whether the four clonal sphere types conformed to the nonclonal sphere groups. Applying two-way ANOVA, the mean expression of GFAP, Hes1, and Hes5 in clones differed from the nonclonal groups $(p=0.0002, p=0.0281$, and $p=$ 0.0195 , respectively). As well, there was a significant increase in the ability of sixth-generation clones to make neurospheres (Table 3). Application of a chi-square test to the data of Table 3 generated a value of $p<0.0001$.

Table 2. Summary of mRNA and Protein Expression in First-Generation Neurospheres

\begin{tabular}{lccc}
\hline Gene & PCR + /- & Sequenced & ICC + /- \\
\hline Nestin & + & + & + \\
CD117 & - & + & - \\
Hes1 & + & + & + \\
Hes5 & + & + & + \\
CD90 & + & + & + \\
TrkA & + & + & + \\
TrkB & + & & + \\
TrkC & + & + & + \\
P75 & + & + & + \\
Oct-4 & - & & - \\
Pax-6 & - & & \\
Lif-r & + & + & + \\
$\beta$-1-Integrin (CD29) & + & + & \\
$\beta-4-$ Integrin (CD104) & - & & \\
CD133 & - & & + \\
CD135 & - & & \\
ICAM-1 (CD54) & + & + & + \\
Presenilin-1 & + & + & \\
Notch-1 & + & + & \\
\hline Positive mRA & & &
\end{tabular}

Positive mRNA expression was evaluated by polymerase chain reaction (PCR) and protein expression assessed by immunocytochemistry (ICC). PCR products were confirmed by sequencing: nestin, CD 117 (c-Kit), Hes1 (hairy enhancer of split 1), Hes5 (hairy enhancer of split 5), CD90 (Thy1.1), TrkA (tyrosine kinase receptor-1), TrkB (tyrosine kinase receptor-2), TrkC (tyrosine kinase receptor-3), P75 (low-affinity neurotrophin receptor), Oct-4 (octamer-binding transcription factor 4), Pax-6 (paired box protein-6), Lif-r (leukemia inhibitory factor receptor), CD29 ( $\beta$-1-integrin), CD104 ( $\beta$-4-integrin), CD133 (prominin 1 ), CD135, intercellular adhesion molecule-1 (ICAM-1) or CD54, presenilin-1, and notch-1.

\section{Coculture Experiments}

Skeletal Muscle. When dissociated olfactory neurosphere cells were plated with skeletal myoblasts that went on to differentiate into some multinucleated myotubes, GFP-positive segments could be seen. These were stained for the coexpression of skeletal myosin. A GFPexpressing myotube subsequently confirmed to express skeletal myosin is shown in Figure 3G-I.

Adipocyte Induction. Two days postconfluence 3T3L1 cells were put into differentiation conditions for 3 days. Differentiation was apparent from the formation of small lipid bodies. The number of differentiated cells and the quantity of accumulated lipid increased during the postdifferentiation period (Fig. 7B). Fully differentiated adipocytes were often found clumped together in large clusters (Fig. 7C). Cells were immunostained in green for Glut-4, an adipocyte marker (Fig. 7C). Control immunocytochemistry, without primary antibody, showed no positive staining.

When cocultured with 3T3-L1 cells GFP-positive dissociated neurosphere cells accumulated lipid and also expressed the adipocyte marker Glut-4, as shown in Figure 7D-G. Differentiated neurosphere cells were only distinguishable from differentiated 3T3-L1 adipocytes by their expression of GFP. In control cultures, none of the GFP-positive neurosphere cells differentiated into adipocytes. There was never any oil red $\mathrm{O}$ staining or Glut-4 immunoreactivity. Control immunocytochemistry, without primary antibody, showed no positive staining.

Transwell Adipocyte Differentiation. Using a transwell coculture assay in which neurosphere cells were exposed to a single round of differentiating 3T3-L1 cells, no differentiation was observed. Neurosphere cells exposed to successive rounds of differentiating 3T3-L1 cells differentiated into adipocytes. In this assay cells are not able to physically make contact. It was concluded that differentiation had taken place based upon the accumulation of lipid and expression of Glut- 4 by dissociated neurosphere cells. Control immunocytochemistry showed no positive staining.

Comparison of Generations in Making Adipocytes. When exposed to successive rounds of differentiating 3T3-L1 cells, first-, second-, and sixth-generation neurosphere cells differentiated into adipocytes. The number of differentiated adipocytes increased with the generations (one-way ANOVA: $p<0.0001$ comparing generation 1 with 6; Bonferroni posttest indicated that the result comparing Gen 1 and 2 could occur by chance) (Fig. 8). It was also calculated that approximately $0.66 \pm 0.14 \%(n=6)$ of sixth-generation neurosphere cells were capable of differentiating into adipocytes. 


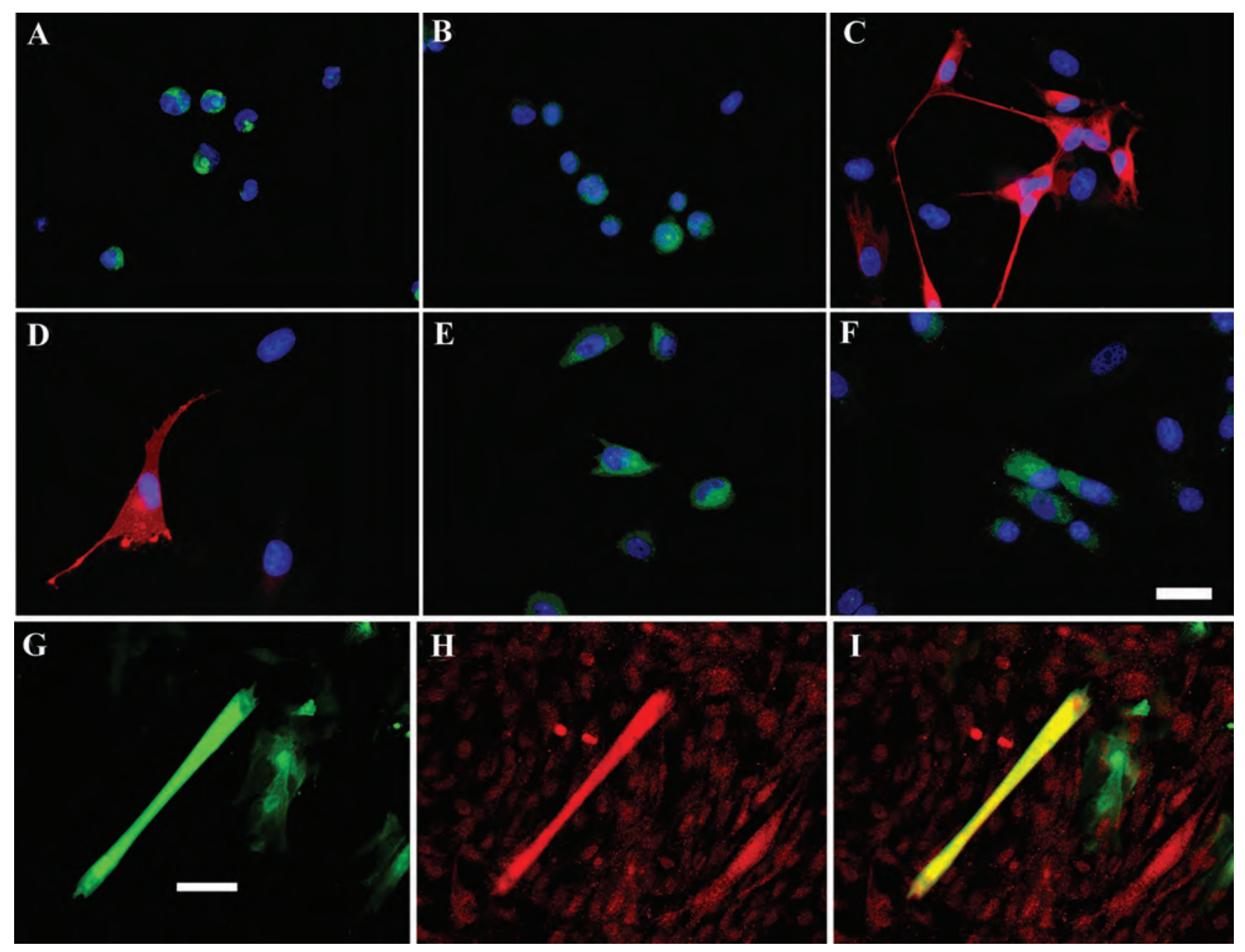

Figure 4. Phenotype of dissociated neurospheres and expanding neurospheres. (A, B) Cytospun dissociated first-generation sphere cells immunopositive for nestin, green (A) and $\beta$-1-integrin, green (B). (C, D) Dissociated first-generation neurospheres expanded in serum containing media for 3 days labeled with nestin, red (C) and P75 (low-affinity neurotrophin receptor), red (D). Dissociated sixth-generation neurospheres expanded in serum containing media for 3 days immunostained for GFAP (glial fibrillary acidic protein), green (E) and $\beta$-1-integrin, green (F). Nuclei were labeled blue using Hoechst. Scale bar: $30 \mu \mathrm{m}$. (G, I) Culture of GFP (green fluorescent protein)-positive, dissociated neurosphere cells with rat neonatal skeletal muscle cells. Cell(s) expressing GFP (G) incorporated into a myotube expressing skeletal muscle myosin, red (H), merged in (I). Scale bar: $30 \mu \mathrm{m}$.

\section{DISCUSSION}

We have established that olfactory neural stem cells are capable of self-renewal and have the potency to differentiate into cells of different tissues. We have established that a clonally derived cell has this capacity. We have determined the proportion of such cells in the population and that these may be increased through generations in vitro. As well, we have established solutions to practical aspects of their culture and potential use in transplantation scenarios.

\section{Self-Renewal}

Our culture strategy involved expansion of cell numbers in a monolayer on plastic, subsequently plating these in sphere-forming conditions, selecting only neurospheres for the next generation of expansion, and then repeating this process. This method was successful at increasing the putative stem cell production for potential application with each successive neurosphere-forming cell generation.

Expansion and the Enrichment of Sphere-Forming Cells. The neurosphere yield (neurospheres $\geq 100 \mu \mathrm{m}$ ) over the six generations, and intervening expansion cultures, represents a cell yield greater than 35 population doublings since initial cell harvest from the olfactory mucosa (Fig. 2, lowest panel). Overall there was enrichment for sphere-forming cells across the generations (Fig. 1D). How are these sphere forming cells enriched? 
The collective cell phenotype of neurospheres remains relatively constant across the generations but the phenotype of intervening expanding sphere-derived cells appears volatile. Neurospheres provide an environment for at least the maintenance of sphere-forming cells. Loss or disruption of this environment, in this case by mechanical and chemical dissociation, might result in a disruption of the maintenance of the sphere-forming population. Overall it is clear that cells growing out adherently in "expanding" conditions vary significantly more in collective phenotype compared to those that constitute olfactory neurospheres themselves. Whether the phenotype of expanding sphere cells changes over the course of the expansion period or not, somehow over time it provides an environment that allows enrichment of sphere-forming cells. As the generations of expanding sphere cells increase, so there is an increase in sphere formation with each generation.

Expansion of olfactory dissociated sphere cells in adherent culture on plastic in the presence of fetal calf serum would be described by many as providing a differentiating environment. Virtually every protocol for the culture of brain-derived neurospheres uses suspension culture and mitogens: EGF and/or FGF2. Induction
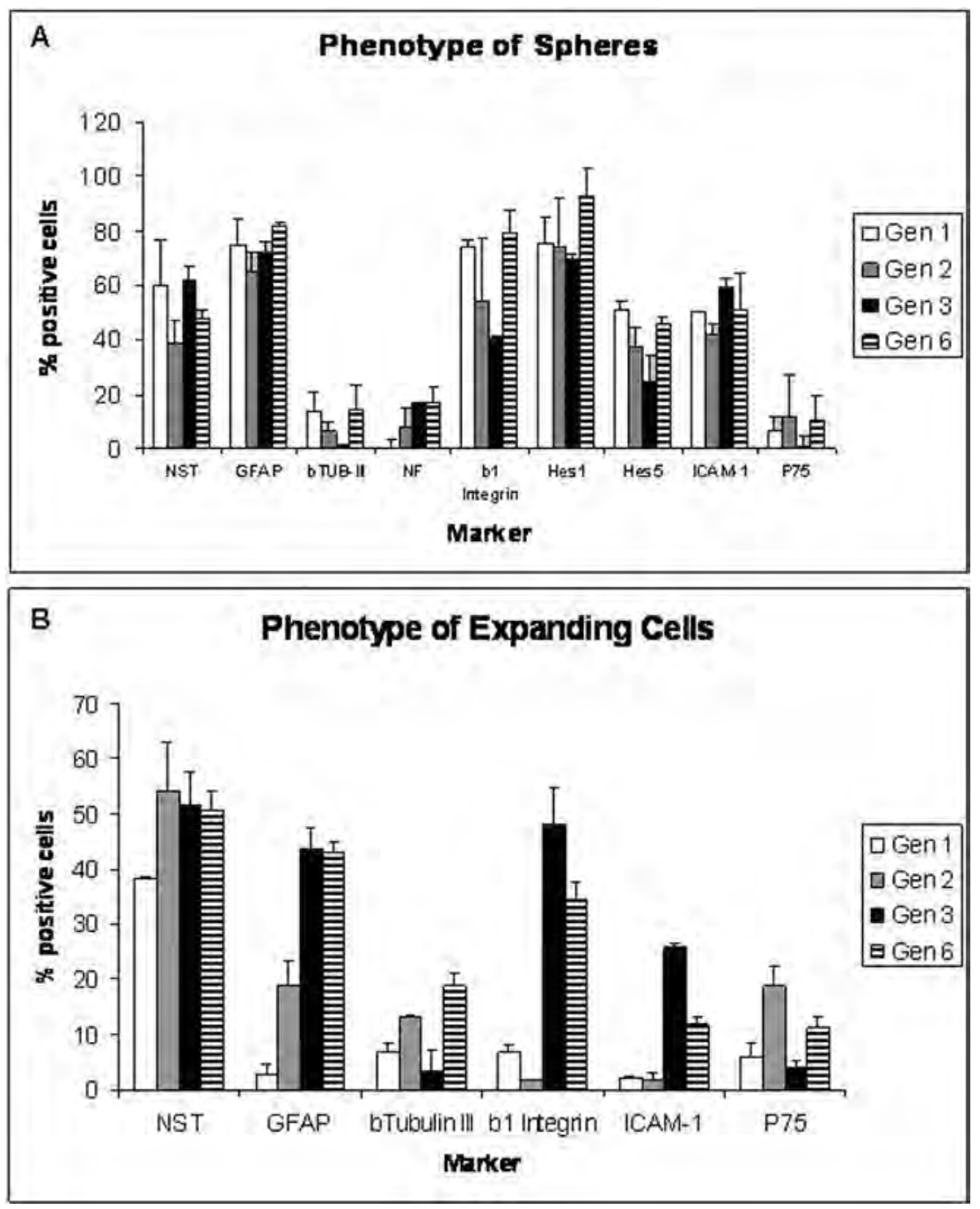

Figure 5. Comparison of the phenotype of neurospheres and dissociated expanding sphere cells across the generations. (A) Phenotype of dissociated spheres expressed as the percentage of positive cells. GFAP, glial fibrillary acidic protein; NST, nestin, bTubulin-III, $\beta$-tubulin III; P75, lowaffinity neurotrophin receptor; blintegrin, $\beta$-1-integrin; ICAM-1, intercellular adhesion molecule 1; Hes1, hairy enhancer of split 1; NF, neurofilament; Hes5, hairy enhancer of split 5. (B) Phenotype of dissociated sphere cells expanded in serum containing media for 3 days expressed as the percentage of positive cells. $n=3$ for all trials. 

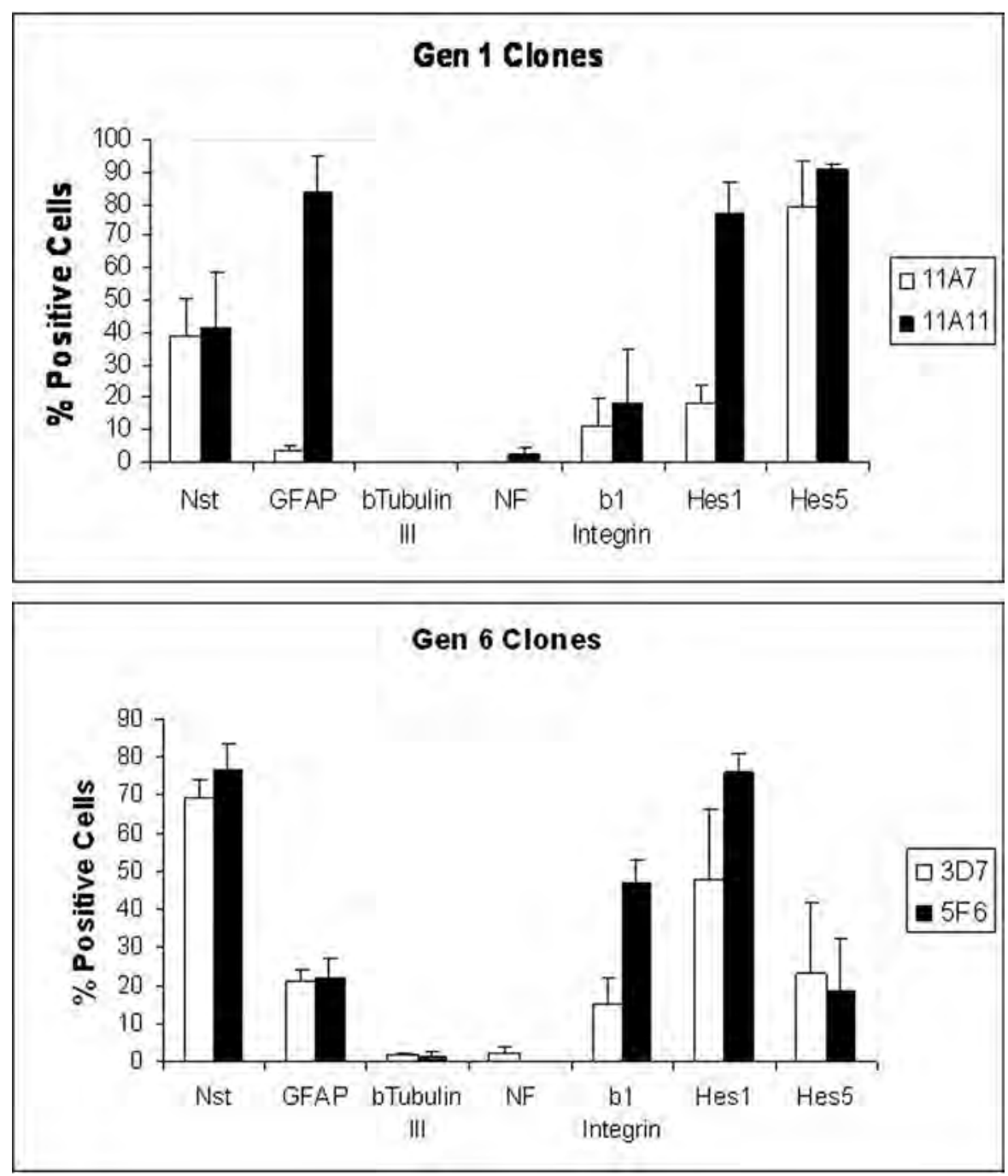

Figure 6. Phenotype of dissociated clonally derived neurospheres expressed as the percentage of positive cells (clones 11A7 and 11A11 are first generation; clones 3D7 and 5F6 are sixth generation). NST, nestin; GFAP, glial fibrillary acidic protein; bTubulin III, $\beta$-tubulin III; NF, neurofilament; b1 integrin, $\beta$-1-integrin; Hes1, hairy enhancer of split 1; Hes5, hairy enhancer of split 5 . Clone 11A7 displays no detectable neural phenotype.

of differentiation is done by subsequent adherent culture in the presence of FCS after withdrawal of mitogens. It could be that in providing FCS and expansion on plastic that we are encouraging differentiation of precursors into more differentiated phenotypes while maintaining genuine stem cells within the population. In this way the actual sphere-forming cells are allowed to proliferate while downstream precursors are provoked into differentiation and are therefore unable to participate in further sphere formation. In this regard, Reynolds and coworkers have provided evidence that in suspension culture brain-derived neurospheres can be formed from both stem cells and precursors $(53,77)$. They have de- vised a method to enrich sphere propagation and longevity by removing small neurospheres (putatively derived from precursors rather than stem cells) from successive generations.

Self-Renewal of Olfactory Sphere-Forming Cells. The phenotype of the neurospheres remained relatively constant across the generations. This uniformity suggests that there is a cell or group of cells that are able to respond to the sphere-forming conditions in a consistent way in each generation. The maintenance of this population through six exposures to sphere formation conditions and six expansion phases requires significant 
self-renewal potential (Fig. 2).The self-renewal potential of dissociated sphere cells was also determined by clonal analysis. In this study cells were plated onto collagen-coated wells at clonal density and allowed to expand in serum-containing media. When clonal cells from firstand sixth-generation neurospheres had expanded it was found that they were able to form secondary neurospheres when plated in sphere-forming conditions, indicating the potential of these clones to self-renew. Interestingly, individual clones generated neurospheres with individual potency. One clone did not contain any cells that displayed neuronal phenotype (for the markers tested). This supports the view of Reynolds and Rietze (77), which suggests neurospheres can form from progenitors as well as stem cells.

Our statistical analysis has assessed that spheres in polyclonal cultures across multiple generations maintain a collectively consistent phenotype whereas cells growing out adherently in "expanding" conditions vary significantly as well as having a lower expression of some markers: GFAP, $\beta$-1-integrin, and ICAM-1. Phenotype for all markers tested from "expanded" cultures was not consistent with generation. With regard to clonal cultures, first-generation clonal spheres differed from sixthgeneration clonal spheres. However, with the small number of clones tested it seemed more relevant to ascertain how well data for the four clones fitted with data for spheres in general (i.e., whether the four clonal spheres conformed to the nonclonal sphere groups). The expression of GFAP, Hes1, and Hes5 in clones differed from the nonclonal groups $(p<0.05)$. A logical conclusion from these data is that spheres descendant from individual cells vary in collective phenotype but spheres of a population are collectively predictable. It would seem that clonal spheres, according to the measure of collective cell phenotype, exhibit dynamics that are "highly sensitive to initial conditions." Considering the issues of cell culture with its multiplicity of variables as well as the individual cell's complement of "determinants" at the time of cloning or sphere formation, this

Table 3. Generation of Clonal Neurospheres: First Versus Sixth Generation

\begin{tabular}{lcc}
\hline & $\begin{array}{c}\text { First } \\
\text { Generation }\end{array}$ & $\begin{array}{c}\text { Sixth } \\
\text { Generation }\end{array}$ \\
\hline Attachment & $39 \%(214 / 514)$ & $80 \%(398 / 495)$ \\
$\begin{array}{l}\text { Proliferative clones } \\
\text { Neurosphere-forming } \\
\quad \text { clones }\end{array}$ & $1.2 \%(8 / 514)$ & $16.1 \%(80 / 495)$ \\
\hline
\end{tabular}

Application of a chi-square test to the above data generated a value of $p=0.0001$, indicating strong statistical significance. seems plausible. On this point it may be mentioned the findings of the Huang group investigating cell dynamics and network theory, who found that even clonal cell populations vary significantly in gene expression at the level of individual cells (15). Subcloning individual cells according to divergence of expression resulted in populations that took many cell divisions to normalize gene expression. Therefore, for the practical purpose of tissue repair by cell transplantation, it seems that derivation of clonal populations of donor cells may be counterproductive.

As well it would seem that we have selected cells more adapted to in vitro conditions. There was a substantial increase in the ability of sixth-generation clones to make neurospheres (Table 3).

We have demonstrated the self-renewal potential of olfactory stem cells by indicating their ability to generate neurospheres using clonal cell lines and by generating and enriching for neurospheres across numerous generations. Interestingly, we have observed that neurospheres can form from one cell or coalesce from several but it is clear that formation of olfactory neurospheres requires environmental contribution from multiple cells.

\section{Multipotency}

Differentiation of GFP-Positive Neurosphere Cells to Express a Skeletal Muscle Marker. Myotubes are syncytia that typically form from the fusion of mononuclear myoblasts. When cultured with neonatal skeletal muscle cells GFP-positive neurosphere cells were present within a skeletal muscle myosin-positive myotube. The formation of a myotube, myogenesis, is a relatively welldefined process divided into distinct stages that include: specification, differentiation, cell-cell recognition, adhesion, alignment, and finally membrane fusion (88). A review of the factors involved in regulating myogenesis revealed that some also have a role in neurogenesis $(3,40,70,89)$. An endorsement of the potentiality of neural progenitor cells to acquire the myogenic lineage is the work of Rietz et al. (80) and Galli and coworkers (28). Utilizing the $\mathrm{C}_{2} \mathrm{C}_{12}$ myoblast cell line (91), both these studies demonstrated that adult neural stem cells, derived from the brain, were accepted as partners in myotube formation.

Induction of Adipocyte Phenotype. The 3T3-L1 preadipocyte cell line was established in 1974 by Green and Meuth after they observed that resting cultures of the embryonic mouse fibroblast cell line 3T3 contained clusters of cells that contained lipid droplets (30). 3T3L1 cells are a cell line that is now known to differentiate consistently into adipocytes in a predictable and ex- 

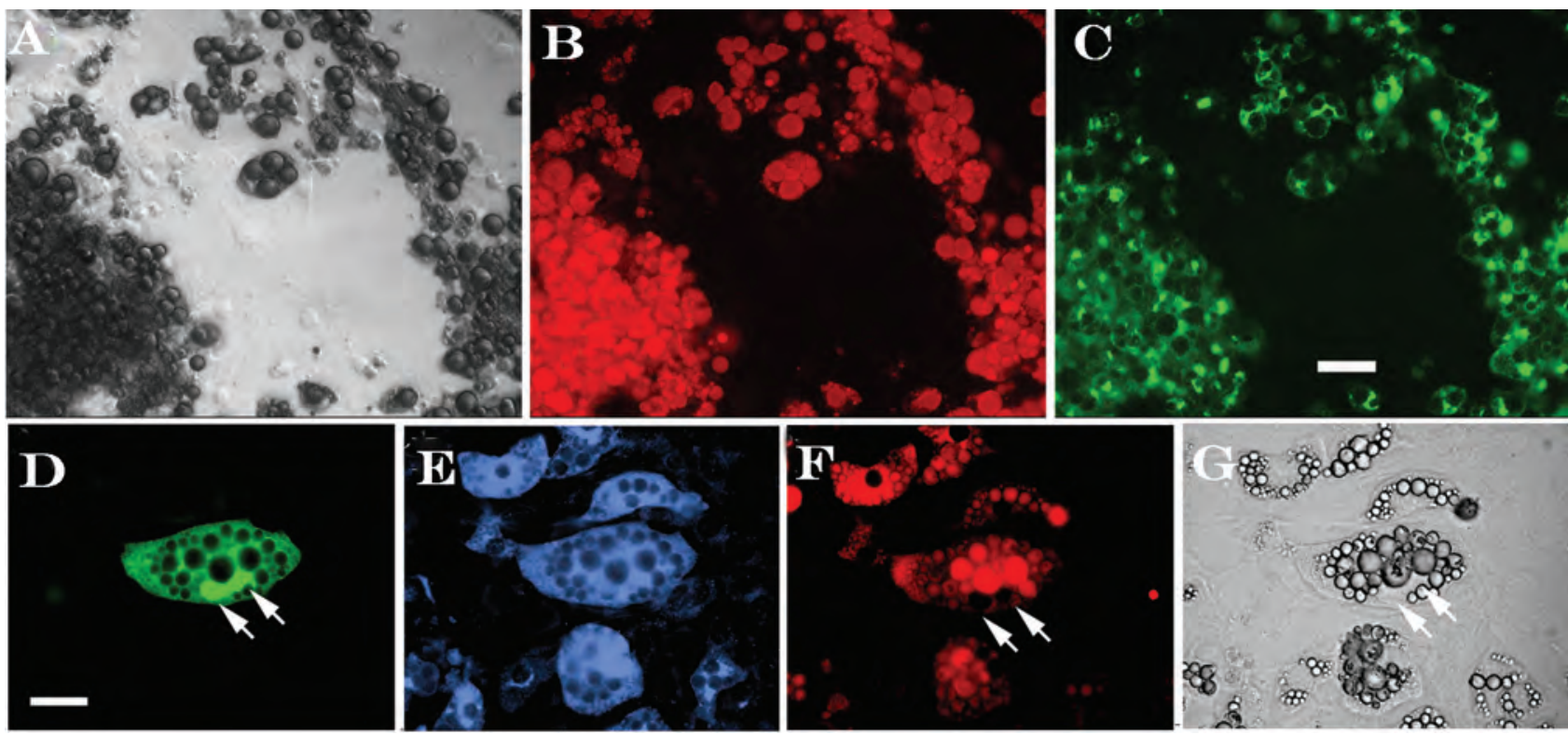

Figure 7. Top panels: differentiated 3T3-L1 cells. During the culture period numerous adipocytes formed usually in clumps. (A) Bright-field image of differentiated adipocytes. (B) Fluorescent image of cells with accumulated lipids stained red with oil red O. (C) Fluorescent image of adipocytes immunostained in green for glucose transporter-4 (Glut-4), an adipocyte marker. Scale bar: 50 $\mu \mathrm{m}$. Lower panels: differentiation of GFP (green fluorescent protein)-positive neurosphere cells into adipocytes. By coculture with 3T3-L1 cells GFP-positive neurosphere cells (D) were found to be immunoreactive for the adipocyte marker Glut-4 (stained blue in E), accumulated lipid (stained red by oil red $\mathrm{O}$ in F), and displayed a typical adipocyte morphology (brightfield G). White arrows: lipid bodies. Scale bar: $30 \mu \mathrm{m}$.

tremely robust manner in well-defined culture conditions. Therefore, coculture with this cell line provided an ideal environment to test for the differentiation of neurosphere cells into a specific cell type. Here it was demonstrated that GFP-positive dissociated neurosphere cells differentiated into adipocytes in a direct contact coculture situation. It was also found that secreted factors produced by $3 \mathrm{~T} 3-\mathrm{L} 1$ cells were sufficient to induce the differentiation of neurosphere cells into adipocytes using a transwell coculture assay.

Stem Cell Numbers Increased With Each Generation. That olfactory neurosphere-derived cells differentiated into adipocytes is a significant finding. That they did this in the absence of cell-cell contact is also significant, but most striking of all is the clear result that with each passing generation of olfactory neurospheres cultivated according to our method there was an enrichment of cells able to respond to the soluble signals emanating from the adipocyte coculture. This result fully supports the enrichment seen in sphere-forming capability in the growth experiments.

\section{Technical Aspects of Olfactory Stem Cell Cultures}

Expansion of Olfactory Mucosa. Initially we attempted to culture dissociated rat olfactory mucosa directly onto PLL-coated wells in EGF and FGF2, but sphere formation was sporadic and inconsistent. An initial cell expansion step on plastic in $10 \%$ serum-containing media was found to be beneficial. Cell numbers increased and more experiments could be carried out with minimal animal use.

The Highest Number of Neurospheres Formed With EGF and FGF2. EGF has been demonstrated to be a mitogen for neural stem cells $(21,78,86)$ as has FGF2 $(32,43,75,79)$, and both factors in combination have been used to expand neural stem cells $(31,45,90)$. Hence, both factors were tested together and in isolation, to determine how olfactory stem cells respond. When expanded olfactory mucosa was passaged onto PLL at high cell density in growth factor-free media (ITS), EGF, FGF2, or EGF and FGF2 it was found that EGF and FGF2 together resulted in the most neurospheres forming. The observation that the number of neurospheres formed in EGF and FGF2 is not cumulative of the number for the relative concentration of each growth factor alone would suggest that each factor is not acting exclusively on a particular cell type. Rather, it would suggest that there is an overlap between the EGF- and FGF2responsive cells. This result is not dissimilar to that obtained by Tropepe and colleagues (18) investigating neural stem cell populations derived from E8.5 mouse telencephalon where FGF2-responsive stem cells 
emerged first followed by an EGF-responsive population. In vitro both populations could respond to either mitogen and their combined effect was additive. A more recent investigation has ascribed the apparent additive effect when both FGF2 and EGF are included to initial commitment of neural and glial precursors swelling cell numbers (58). They attribute self-renewal mainly to FGF2. In our experiment ITS media failed to generate significant numbers of neurospheres, indicating that high plating density and the PLL coating alone cannot account for sphere formation; mitogenic assistance is required.

Cell Density. While neural stem cells derived from the brain are able to form neurospheres in clonal conditions $(32,65)$, neither freshly dissociated olfactory mucosa nor dissociated sphere cells were able to proliferate at clonal dilution in sphere-forming conditions, highlighting the importance of cell-cell interaction in sphere formation. This could have been due to a need for cell contact or for trophic factor exchange. The importance of cell density in the formation of neurospheres has been emphasized by the observation that neural stem cell proliferation is increased when cells are grown at high density in EGF and FGF2 (66). Therefore, when expanded primary olfactory mucosa cultures were plated in sphereforming conditions, a range of cell plating densities was tested to determine the optimal cell density for sphere formation.

Comparison of Generations. The concentration curve observed for the formation of first-generation neurospheres at different cell densities indicates that the optimal cell density is 50,000 cells $/ \mathrm{cm}^{2}$ and that there is a slight decrease in sphere numbers at lower cell densities. Similarly, there is a decrease in the number of neurospheres as the cell density increases. However, the formation of later generation neurospheres was characterized by an overall increase in sphere numbers, indicating a significant enrichment of sphere forming cells. Similar to other generations there was a dramatic drop in sphere numbers above a particular cell density.

Olfactory Sphere Populations Displayed a Consistent Phenotype. Olfactory neurospheres contain a heterogeneous population of cells, including committed precursors or progenitor cells, neurons, glia, and presumably stem cells. Here we show that these neurospheres contain nestin-positive precursor or progenitor cells. While it is apparent that these nestin-positive cells are able to give rise to both neurons ( $\beta$-tubulin- $\mathrm{III}^{+}$and neurofilament ${ }^{+}$) and glia $\left(\right.$GFAP $\left.^{+}\right)$, it is evident that olfactory neurospheres generated in the conditions established here predominantly give rise to glial cells, not neurons, in contrast to the studies reported by Roisen and colleagues $(81,93)$, where $\beta$-tubulin-III ${ }^{+}$precursors prevailed in the culture conditions they described. While their role as mitogens for neural progenitors seems clear, the role of EGF and FGF2 in determining the fate of proliferating progenitors is less clear. FGF2, for example, has been demonstrated to be proneurogenic in some situations $(62,74)$ and in others to inhibit neurogenesis and promote gliogenesis $(64,75,92)$. Similarly, EGF has been reported to induce both neural $(23,76)$ and glial $(11,47)$ fates.

In our hands EGF and FGF2 in combination produce

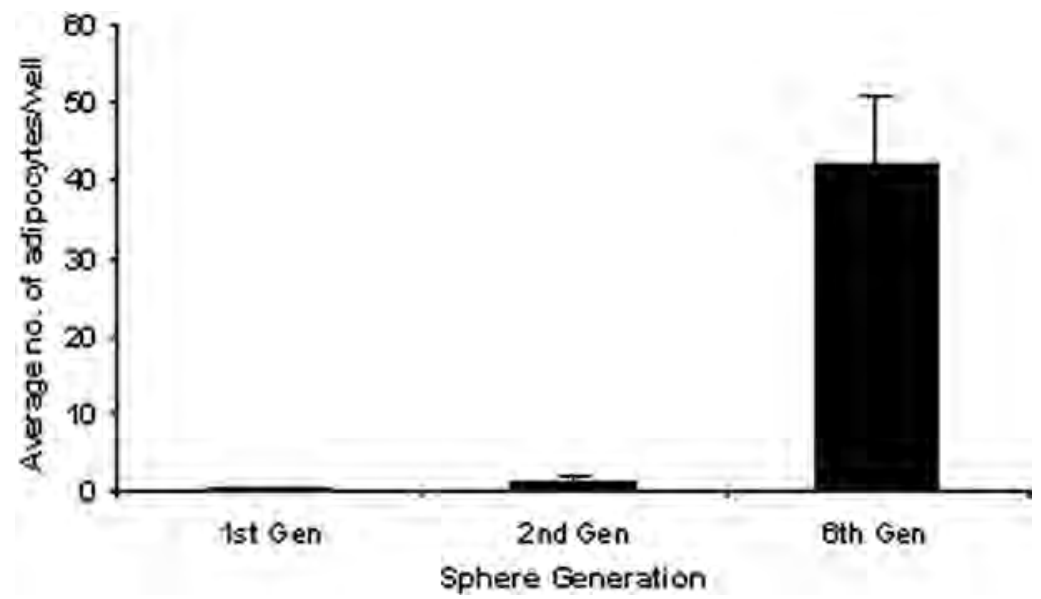

Figure 8. Increase in differentiation capability of first-, second-, and sixth-generation dissociated neurosphere cells into adipocytes. Dissociated neurosphere cells were cultured beneath 3T3-L1 cells growing on tissue culture inserts. The number of Glut-4- and oil red O-positive cells for each generation was counted. 
olfactory precursors that differentiate predominantly into glial cells. A possible mechanism for the inhibition of neuronal differentiation or, alternately, the promotion of glial differentiation is indicated by the high expression of the repressor-type basic helix-loop-helix (bHLH) genes Hes 1 and Hes5 in olfactory neurospheres. Hes1 and Hes5 have been shown to be highly expressed by neural stem cells $(1,2,83)$ and are essential for their proliferation and maintenance $(14,38,71)$. Hes 1 and Hes5 have also been demonstrated to be inhibitors of neuronal differentiation by antagonizing the activator-type bHLH genes, which include mammalian achaete-schute homo$\log 1$ (Mash1), mammalian atonal protein homolog (Math), and neurogenin (16,83). A more proactive role in the promotion of gliogenesis is suggested by the increased generation of Muller glia in the retina with the mis-expression of Hes1 and Hes5 (25,35,72). Hes1 and Hes 5 expression is regulated by notch (expressed by first-generation neurospheres) signaling $(41,72)$, which is also known to inhibit neuronal differentiation and maintain neural stem cells (26). Interestingly, it has been demonstrated that notch signaling may promote differentiation of glia from neural progenitors in the embryonic forebrain (27). Similarly, Tanigaki and coworkers (85) have shown an instructive role for notch-1 in the induction of an astroglial fate in FGF2-responsive adult hippocampus-derived neural progenitors. It has also been found that first-generation neurospheres express presenilin-1, which is important for notch signaling in the central nervous system $(4,34,46)$. Taken as a whole the presenilin-notch-Hes1/Hes5 pathway may maintain the self-renewal of the olfactory stem cells found in neurospheres, as well as promote a glial lineage in preference to a neuronal lineage.

Similar to notch signaling, the expression of $\beta$-1-integrin is associated with maintaining stem cells in an undifferentiated state $(8,12,50,94)$. Interestingly, $\beta$-1-integrin is expressed in the horizontal basal cells of the olfactory epithelium (13); however, its expression has been more thoroughly examined in the epidermis. In the skin it has been demonstrated that selecting for cells with the highest expression of $\beta$-1-integrin enriches for stem cells $(42,44)$ and that a decrease in $\beta$-1-integrin expression is associated with a depletion of stem cells and an increase in differentiation $(33,94)$. The high expression of $\beta$-1-integrin in olfactory neurospheres may indicate a defining role in the stem cell niche and as well promote cell adhesion to maintain the structure of the sphere.

Reported Use of Olfactory Stem Cells in Human Transplant. There are many internet sites from a number of countries of private clinics offering cell or tissue transplant therapy for humans with varying disease or injury disabilities. Quite a proportion of these offer "ol- factory"-derived tissue or cells. Usually bona fide publications are referred to in the advertisement as credentials for the procedures. In some cases the cells are nonautologous fetal cells. Some offer autologous transplant of uncultured tissue. There are usually no scientific publications by the groups; only medical staff are named and no credentials or protocols for preparation or culture of the tissue are given. The Carlos Lima group of Portugal have scientific credibility and have recently published a human trial using olfactory autografts for spinal repair (52). The group says they cultured olfactory stem cells for six of the patients but no protocols are published for the culture.

\section{CONCLUSION}

We have addressed pragmatic issues pertinent to using olfactory neural stem cells for tissue repair. The olfactory neural stem cell is emerging as potentially a most significant candidate of all possible sources for human tissue repair strategies. It can be derived from adult humans; a patient's own cells are readily available from minimally invasive biopsy; it can be grown in defined media; source cell numbers present a higher percentage capability than iPS cells (for instance); it does not produce teratomas upon xenotransplantation (ES and iPS cells); it has performed well in preclinical models of disease and transplantation-hematopoietic, Parkinson's, herniated disc, and heart attack (61,67-69); and it seems to emulate a wound-healing process where the cells acquire appropriate phenotype in an apparently orderly fashion over time.

\section{REFERENCES}

1. Akazawa, C.; Sasai, Y.; Nakanishi, S.; Kageyama, R. Molecular characterization of a rat negative regulator with a basic helix-loop-helix structure predominantly expressed in the developing nervous system. J. Biol. Chem. 267(30): 21879-21885; 1992.

2. Allen, T.; Lobe, C. G. A comparison of Notch, Hes and Grg expression during murine embryonic and post-natal development. Cell. Mol. Biol. 45(5):687-708; 1999.

3. Baylies, M. K.; Bate, M.; Ruiz Gomez, M. Myogenesis: A view from Drosophila. Cell 93(6):921-927; 1998.

4. Beatus, P.; Lendahl, U. Notch and neurogenesis. J. Neurosci. Res. 54(2):125-136; 1998.

5. Bianco, J. I.; Perry, C.; Harkin, D. G.; Mackay-Sim, A.; Feron, F. Neurotrophin 3 promotes purification and proliferation of olfactory ensheathing cells from human nose. Glia 45(2):111-123; 2004.

6. Bjornson, C. R.; Rietze, R. L.; Reynolds, B. A.; Magli, M. C.; Vescovi, A. L. Turning brain into blood: A hematopoietic fate adopted by adult neural stem cells in vivo. Science 283(5401):534-537; 1999.

7. Blandini, F.; Cova, L.; Armentero, M. T.; Zennaro, E.; Levandis, G.; Bossolasco, P.; Calzarossa, C.; Mellone, M.; Giuseppe, B.; Deliliers, G. L.; Polli, E.; Nappi, G.; Silani, V. Transplantation of undifferentiated human mesenchymal stem cells protects against 6-hydroxydopamine neurotoxicity in the rat. Cell Transplant. 19(2):203-217; 2010. 
8. Brakebusch, C.; Grose, R.; Quondamatteo, F.; Ramirez, A.; Jorcano, J. L.; Pirro, A.; Svensson, M.; Herken, R.; Sasaki, T.; Timpl, R.; Werner, S.; Fassler, R. Skin and hair follicle integrity is crucially dependent on beta 1 integrin expression on keratinocytes. EMBO J. 19(15):39904003; 2000.

9. Brazelton, T. R.; Rossi, F. M.; Keshet, G. I.; Blau, H. M. From marrow to brain: Expression of neuronal phenotypes in adult mice. Science 290(5497):1775-1779; 2000.

10. Calof, A. L.; Chikaraishi, D. M. Analysis of neurogenesis in a mammalian neuroepithelium: Proliferation and differentiation of an olfactory neuron precursor in vitro. Neuron 3(1):115-127; 1989.

11. Cameron, H. A.; Hazel, T. G.; McKay, R. D. Regulation of neurogenesis by growth factors and neurotransmitters. J. Neurobiol. 36(2):287-306; 1998.

12. Campos, L. S.; Leone, D. P.; Relvas, J. B.; Brakebusch, C.; Fassler, R.; Suter, U.; ffrench-Constant, C. Beta1 integrins activate a MAPK signalling pathway in neural stem cells that contributes to their maintenance. Development 131(14):3433-3444; 2004

13. Carter, L. A.; MacDonald, J. L.; Roskams, A. J. Olfactory horizontal basal cells demonstrate a conserved multipotent progenitor phenotype. J. Neurosci. 24(25):5670-5683; 2004

14. Cau, E.; Gradwohl, G.; Casarosa, S.; Kageyama, R.; Guillemot, F. Hes genes regulate sequential stages of neurogenesis in the olfactory epithelium. Development 127(11): 2323-2332; 2000.

15. Chang, H.; Hemberg, M.; Barahona, M.; Ingber, D.; Huang, S. Transcriptome-wide noise controls lineage choice in mammalian progenitor cells. Nature 453:544547; 2008.

16. Chen, H.; Thiagalingam, A.; Chopra, H.; Borges, M. W.; Feder, J. N.; Nelkin, B. D.; Baylin, S. B.; Ball, D. W. Conservation of the Drosophila lateral inhibition pathway in human lung cancer: A hairy-related protein (HES-1) directly represses achaete-scute homolog-1 expression. Proc. Natl. Acad. Sci. USA 94(10):5355-5360; 1997.

17. Chen, X.; Fang, H.; Schwob, J. E. Multipotency of purified, transplanted globose basal cells in olfactory epithelium. J. Comp. Neurol. 469(4):457-474; 2004.

18. Chiasson, B. J.; Tropepe, V.; Morshead, C. M.; van der Kooy, D. Adult mammalian forebrain ependymal and subependymal cells demonstrate proliferative potential, but only subependymal cells have neural stem cell characteristics. J. Neurosci. 19(11):4462-4471; 1999.

19. Chomczynski, P.; Sacchi, N. Single-step method of RNA isolation by acid guanidinium thiocyanate-phenol-chloroform extraction. Anal. Biochem. 162(1):156-159; 1987.

20. Clarke, D. L.; Johansson, C. B.; Wilbertz, J.; Veress, B.; Nilsson, E.; Karlstrom, H.; Lendahl, U.; Frisen, J. Generalized potential of adult neural stem cells. Science 288(5471):1660-1663; 2000

21. Craig, C. G.; Tropepe, V.; Morshead, C. M.; Reynolds, B. A.; Weiss, S.; van der Kooy, D. In vivo growth factor expansion of endogenous subependymal neural precursor cell populations in the adult mouse brain. J. Neurosci. 16(8):2649-2658; 1996.

22. Eglitis, M. A.; Mezey, E. Hematopoietic cells differentiate into both microglia and macroglia in the brains of adult mice. Proc. Natl. Acad. Sci. USA 94(8):4080-4085; 1997.

23. Enwere, E.; Shingo, T.; Gregg, C.; Fujikawa, H.; Ohta, S.; Weiss, S. Aging results in reduced epidermal growth factor receptor signaling, diminished olfactory neurogenesis, and deficits in fine olfactory discrimination. J. Neurosci. 24(38):8354-8365; 2004

24. Feron, F.; Mackay-Sim, A.; Andrieu, J. L.; Matthaei, K. I.; Holley, A.; Sicard, G. Stress induces neurogenesis in non-neuronal cell cultures of adult olfactory epithelium. Neuroscience 88(2):571-583; 1999.

25. Furukawa, T.; Mukherjee, S.; Bao, Z. Z.; Morrow, E. M.; Cepko, C. L. rax, Hes1, and notch1 promote the formation of Muller glia by postnatal retinal progenitor cells. Neuron 26(2):383-394; 2000.

26. Gaiano, N.; Fishell, G. The role of notch in promoting glial and neural stem cell fates. Annu. Rev. Neurosci. 25: 471-490; 2002.

27. Gaiano, N.; Nye, J. S.; Fishell, G. Radial glial identity is promoted by Notch1 signaling in the murine forebrain. Neuron 26(2):395-404; 2000.

28. Galli, R.; Borello, U.; Gritti, A.; Minasi, M. G.; Bjornson, C.; Coletta, M.; Mora, M.; De Angelis, M. G.; Fiocco, R.; Cossu, G.; Vescovi, A. L. Skeletal myogenic potential of human and mouse neural stem cells. Nat. Neurosci. 3(10): 986-991; 2000.

29. Graziadei, P. P.; Levine, R. R.; Monti Graziadei, G. A. Plasticity of connections of the olfactory sensory neuron: Regeneration into the forebrain following bulbectomy in the neonatal mouse. Neuroscience 4(6):713-727; 1979.

30. Green, H.; Meuth, M. An established pre-adipose cell line and its differentiation in culture. Cell 3(2):127-133; 1974.

31. Gritti, A.; Frolichsthal-Schoeller, P.; Galli, R.; Parati, E. A.; Cova, L.; Pagano, S. F.; Bjornson, C. R.; Vescovi, A. L. Epidermal and fibroblast growth factors behave as mitogenic regulators for a single multipotent stem celllike population from the subventricular region of the adult mouse forebrain. J. Neurosci. 19(9):3287-3297; 1999.

32. Gritti, A.; Parati, E. A.; Cova, L.; Frolichsthal, P.; Galli, R.; Wanke, E.; Faravelli, L.; Morassutti, D. J.; Roisen, F.; Nickel, D. D.; Vescovi, A. L. Multipotential stem cells from the adult mouse brain proliferate and self-renew in response to basic fibroblast growth factor. J. Neurosci. 16(3):1091-1100; 1996.

33. Grose, R.; Hutter, C.; Bloch, W.; Thorey, I.; Watt, F. M.; Fassler, R.; Brakebusch, C.; Werner, S. A crucial role of beta 1 integrins for keratinocyte migration in vitro and during cutaneous wound repair. Development 129(9): 2303-2315; 2002.

34. Hitoshi, S.; Alexson, T.; Tropepe, V.; Donoviel, D.; Elia, A. J.; Nye, J. S.; Conlon, R. A.; Mak, T. W.; Bernstein, A.; van der Kooy, D. Notch pathway molecules are essential for the maintenance, but not the generation, of mammalian neural stem cells. Genes Dev. 16(7):846-858; 2002.

35. Hojo, M.; Ohtsuka, T.; Hashimoto, N.; Gradwohl, G.; Guillemot, F.; Kageyama, R. Glial cell fate specification modulated by the bHLH gene Hes 5 in mouse retina. Development 127(12):2515-2522; 2000.

36. Huard, J. M.; Youngentob, S. L.; Goldstein, B. J.; Luskin, M. B.; Schwob, J. E. Adult olfactory epithelium contains multipotent progenitors that give rise to neurons and nonneural cells. J. Comp. Neurol. 400(4):469-486; 1998.

37. Ianus, A.; Holz, G. G.; Theise, N. D.; Hussain, M. A. In vivo derivation of glucose-competent pancreatic endocrine cells from bone marrow without evidence of cell fusion. J. Clin. Invest. 111(6):843-850; 2003.

38. Ishibashi, M.; Ang, S. L.; Shiota, K.; Nakanishi, S.; Kageyama, R.; Guillemot, F. Targeted disruption of mammalian hairy and Enhancer of split homolog-1 (HES-1) leads 
to up-regulation of neural helix-loop-helix factors, premature neurogenesis, and severe neural tube defects. Genes Dev. 9(24):3136-3148; 1995.

39. Jackson, K. A.; Majka, S. M.; Wang, H.; Pocius, J.; Hartley, C. J.; Majesky, M. W.; Entman, M. L.; Michael, L. H.; Hirschi, K. K.; Goodell, M. A. Regeneration of ischemic cardiac muscle and vascular endothelium by adult stem cells. J. Clin. Invest. 107(11):1395-1402; 2001.

40. Jan, Y. N.; Jan, L. Y. HLH proteins, fly neurogenesis, and vertebrate myogenesis. Cell 75(5):827-830; 1993.

41. Jarriault, S.; Brou, C.; Logeat, F.; Schroeter, E. H.; Kopan, R.; Israel, A. Signalling downstream of activated mammalian Notch. Nature 377(6547):355-358; 1995.

42. Jensen, U. B.; Lowell, S.; Watt, F. M. The spatial relationship between stem cells and their progeny in the basal layer of human epidermis: A new view based on wholemount labelling and lineage analysis. Development 126(11):2409-2418; 1999.

43. Johe, K. K.; Hazel, T. G.; Muller, T.; Dugich-Djordjevic, M. M.; McKay, R. D. Single factors direct the differentiation of stem cells from the fetal and adult central nervous system. Genes Dev. 10(24):3129-3140; 1996.

44. Jones, P. H.; Harper, S.; Watt, F. M. Stem cell patterning and fate in human epidermis. Cell 80(1):83-93; 1995.

45. Kilpatrick, T. J.; Bartlett, P. F. Cloned multipotential precursors from the mouse cerebrum require FGF-2, whereas glial restricted precursors are stimulated with either FGF2 or EGF. J. Neurosci. 15(5 Pt. 1):3653-3661; 1995.

46. Koo, E. H.; Kopan, R. Potential role of presenilin-regulated signaling pathways in sporadic neurodegeneration. Nat. Med. 10(Suppl.):S26-33; 2004.

47. Kuhn, H. G.; Winkler, J.; Kempermann, G.; Thal, L. J.; Gage, F. H. Epidermal growth factor and fibroblast growth factor-2 have different effects on neural progenitors in the adult rat brain. J. Neurosci. 17(15):5820-5829; 1997.

48. Lagasse, E.; Connors, H.; Al-Dhalimy, M.; Reitsma, M.; Dohse, M.; Osborne, L.; Wang, X.; Finegold, M.; Weissman, I. L.; Grompe, M. Purified hematopoietic stem cells can differentiate into hepatocytes in vivo. Nat. Med. 6(11):1229-1234; 2000.

49. Leung, C. T.; Coulombe, P. A.; Reed, R. R. Contribution of olfactory neural stem cells to tissue maintenance and regeneration. Nat. Neurosci. 10(6):720-726; 2007.

50. Levy, L.; Broad, S.; Diekmann, D.; Evans, R. D.; Watt, F. M. beta1 integrins regulate keratinocyte adhesion and differentiation by distinct mechanisms. Mol. Biol. Cell 11(2):453-466; 2000

51. Li, Y.; Decherchi, P.; Raisman, G. Transplantation of olfactory ensheathing cells into spinal cord lesions restores breathing and climbing. J. Neurosci. 23(3):727-731; 2003.

52. Lima, C.; Escada, P.; Pratas-Vidal, J.; Branco, C.; Arcangeli, C.; Lazzeri, G.; Maia, C.; Capucho, C.; HasseFerreira, A.; Peduzzi, J. Olfactory mucosal autografts and rehabilitation for chronic traumatic spinal cord injury. Neurorehabil. Neural Repair 24(1):10-22; 2010.

53. Louis, S. A.; Rietze, R. L.; Deleyrolle, L.; Wagey, R. E.; Thomas, T. E.; Eaves, A. C.; Reynolds, B. A. Enumeration of neural stem and progenitor cells in the neural colony-forming cell assay. Stem Cells 26(4):988-996; 2008.

54. Lu, J.; Feron, F.; Mackay-Sim, A.; Waite, P. M. Olfactory ensheathing cells promote locomotor recovery after delayed transplantation into transected spinal cord. Brain 125(Pt. 1):14-21; 2002.

55. Ma, Y. H.; Zhang, Y.; Cao, L.; Su, J. C.; Wang, Z. W.;
$\mathrm{Xu}$, A. B.; Zhang, S. C. Effect of neurotrophin-3 genetically modified olfactory ensheathing cells transplantation on spinal cord injury. Cell Transplant. 19(2):167-177; 2010.

56. Mackay-Sim, A.; Feron, F.; Cochrane, J.; Bassingthwaighte, L.; Bayliss, C.; Davies, W.; Fronek, P.; Gray, C.; Kerr, G.; Licina, P.; Nowitzke, A.; Perry, C.; Silburn, P. A.; Urquhart, S.; Geraghty, T. Autologous olfactory ensheathing cell transplantation in human paraplegia: A 3year clinical trial. Brain 131(Pt. 9):2376-2386; 2008.

57. Mackay-Sim, A.; Kittel, P. Cell dynamics in the adult mouse olfactory epithelium: A quantitative autoradiographic study. J. Neurosci. 11(4):979-984; 1991.

58. Maric, D.; Maric, I.; Chang, Y. H.; Barker, J. L. Prospective cell sorting of embryonic rat neural stem cells and neuronal and glial progenitors reveals selective effects of basic fibroblast growth factor and epidermal growth factor on self-renewal and differentiation. J. Neurosci. 23(1): 240-251; 2003.

59. Masuya, M.; Drake, C. J.; Fleming, P. A.; Reilly, C. M.; Zeng, H.; Hill, W. D.; Martin-Studdard, A.; Hess, D. C.; Ogawa, M. Hematopoietic origin of glomerular mesangial cells. Blood 101(6):2215-2218; 2003.

60. Matigian, N.; Abrahamsen, G.; Sutharsan, R.; Cook, A. L.; Vitale, A. M.; Nouwens, A.; Bellette, B.; An, J.; Anderson, M.; Beckhouse, A. G.; Bennebroek, M.; Cecil, R.; Chalk, A. M.; Cochrane, J.; Fan, Y.; Feron, F.; McCurdy, R.; McGrath, J. J.; Murrell, W.; Perry, C.; Raju, J.; Ravishankar, S.; Silburn, P. A.; Sutherland, G. T.; Mahler, S.; Mellick, G. D.; Wood, S. A.; Sue, C. M.; Wells, C. A.; Mackay-Sim, A. Disease-specific, neurosphere-derived cells as models for brain disorders. Dis. Model. Mech. 3(11-12):785-798; 2010.

61. McDonald, C.; Mackay-Sim, A.; Crane, D.; Murrell, W. Could cells from your nose fix your heart? Transplantation of olfactory stem cells in a rat model of cardiac infarction. Scientific World J. 10:422-433; 2010.

62. Menard, C.; Hein, P.; Paquin, A.; Savelson, A.; Yang, X. M.; Lederfein, D.; Barnabe-Heider, F.; Mir, A. A.; Sterneck, E.; Peterson, A. C.; Johnson, P. F.; Vinson, C.; Miller, F. D. An essential role for a MEK-C/EBP pathway during growth factor-regulated cortical neurogenesis. Neuron 36(4):597-610; 2002.

63. Mezey, E.; Chandross, K. J.; Harta, G.; Maki, R. A.; McKercher, S. R. Turning blood into brain: Cells bearing neuronal antigens generated in vivo from bone marrow. Science 290(5497):1779-1782; 2000.

64. Morrow, T.; Song, M. R.; Ghosh, A. Sequential specification of neurons and glia by developmentally regulated extracellular factors. Development 128(18):3585-3594; 2001.

65. Morshead, C. M.; Craig, C. G.; van der Kooy, D. In vivo clonal analyses reveal the properties of endogenous neural stem cell proliferation in the adult mammalian forebrain. Development 125(12):2251-2261; 1998.

66. Morshead, C. M.; van der Kooy, D. Disguising adult neural stem cells. Curr. Opin. Neurobiol. 14(1):125-131; 2004.

67. Murrell, W.; Feron, F.; Wetzig, A.; Cameron, N.; Splatt, K.; Bellette, B.; Bianco, J.; Perry, C.; Lee, G.; MackaySim, A. Multipotent stem cells from adult olfactory mucosa. Dev. Dyn. 233(2):496-515; 2005.

68. Murrell, W.; Sanford, E.; Anderberg, L.; Cavanagh, B.; Mackay-Sim, A. Olfactory stem cells can be induced to express chondrogenic phenotype in a rat intervertebral disc injury model. Spine J. 9(7):585-594; 2009. 
69. Murrell, W.; Wetzig, A.; Donnellan, M.; Feron, F.; Burne, T.; Meedeniya, A.; Kesby, J.; Bianco, J.; Perry, C. Silburn, P.; Mackay-Sim, A. Olfactory mucosa is a potential source for autologous stem cell therapy for Parkinson's disease. Stem Cells 26:2183-2192; 2008.

70. Nye, J. S.; Kopan, R.; Axel, R. An activated Notch suppresses neurogenesis and myogenesis but not gliogenesis in mammalian cells. Development 120(9):2421-2430; 1994.

71. Ohtsuka, T.; Ishibashi, M.; Gradwohl, G.; Nakanishi, S.; Guillemot, F.; Kageyama, R. Hes1 and Hes5 as notch effectors in mammalian neuronal differentiation. EMBO J. 18(8):2196-2207; 1999.

72. Ohtsuka, T.; Sakamoto, M.; Guillemot, F.; Kageyama, R. Roles of the basic helix-loop-helix genes Hes1 and Hes5 in expansion of neural stem cells of the developing brain. J. Biol. Chem. 276(32):30467-30474; 2001.

73. Orlic, D.; Kajstura, J.; Chimenti, S.; Jakoniuk, I.; Anderson, S. M.; Li, B.; Pickel, J.; McKay, R.; Nadal-Ginard, B.; Bodine, D. M.; Leri, A.; Anversa, P. Bone marrow cells regenerate infarcted myocardium. Nature 410(6829): 701-705; 2001.

74. Palmer, T. D.; Markakis, E. A.; Willhoite, A. R.; Safar, F.; Gage, F. H. Fibroblast growth factor-2 activates a latent neurogenic program in neural stem cells from diverse regions of the adult CNS. J. Neurosci. 19(19):8487-8497; 1999.

75. Qian, X.; Davis, A. A.; Goderie, S. K.; Temple, S. FGF2 concentration regulates the generation of neurons and glia from multipotent cortical stem cells. Neuron 18(1):81-93; 1997.

76. Raineteau, O.; Rietschin, L.; Gradwohl, G.; Guillemot, F.; Gahwiler, B. H. Neurogenesis in hippocampal slice cultures. Mol. Cell. Neurosci. 26(2):241-250; 2004.

77. Reynolds, B. A.; Rietze, R. L. Neural stem cells and neurospheres-re-evaluating the relationship. Nat. Methods 2(5):333-336; 2005.

78. Reynolds, B. A.; Weiss, S. Generation of neurons and astrocytes from isolated cells of the adult mammalian central nervous system. Science 255(5052):1707-1710; 1992.

79. Richards, L. J.; Kilpatrick, T. J.; Bartlett, P. F. De novo generation of neuronal cells from the adult mouse brain. Proc. Natl. Acad. Sci. USA 89(18):8591-8595; 1992.

80. Rietze, R. L.; Valcanis, H.; Brooker, G. F.; Thomas, T.; Voss, A. K.; Bartlett, P. F. Purification of a pluripotent neural stem cell from the adult mouse brain. Nature 412(6848):736-739; 2001.

81. Roisen, F. J.; Klueber, K. M.; Lu, C. L.; Hatcher, L. M.; Dozier, A.; Shields, C. B.; Maguire, S. Adult human olfactory stem cells. Brain Res. 890(1):11-22; 2001.

82. Rooke, H. The International Society for Stem Cell Re- search (ISSCR): History and perspectives. Regen. Med. 1(3):373-376; 2006.

83. Sasai, Y.; Kageyama, R.; Tagawa, Y.; Shigemoto, R.; Nakanishi, S. Two mammalian helix-loop-helix factors structurally related to Drosophila hairy and Enhancer of split. Genes Dev. 6(12B):2620-2634; 1992.

84. Sipp, D. Stem cell research in Asia: A critical view. J. Cell. Biochem. 107:853-856; 2009.

85. Tanigaki, K.; Nogaki, F.; Takahashi, J.; Tashiro, K.; Kurooka, H.; Honjo, T. Notch1 and Notch3 instructively restrict bFGF-responsive multipotent neural progenitor cells to an astroglial fate. Neuron 29(1):45-55; 2001.

86. Tropepe, V.; Craig, C. G.; Morshead, C. M.; van der Kooy, D. Transforming growth factor-alpha null and senescent mice show decreased neural progenitor cell proliferation in the forebrain subependyma. J. Neurosci. 17(20): 7850-7859; 1997.

87. Vadlamudi, L.; Dibbens, L. M.; Lawrence, K. M.; Iona, X.; McMahon, J. M.; Murrell, W.; Mackay-Sim, A.; Scheffer, I. E.; Berkovic, S. F. Timing of de novo mutagenesis - a twin study of sodium-channel mutations. N. Engl. J. Med. 363(14):1335-1340; 2010.

88. Wakelam, M. J. The fusion of myoblasts. Biochem. J. 228(1):1-12; 1985.

89. Weintraub, H.; Davis, R.; Tapscott, S.; Thayer, M.; Krause, M.; Benezra, R.; Blackwell, T. K.; Turner, D.; Rupp, R.; Hollenberg, S.; Zhuang, Y.; Lassar, A. The myoD gene family: Nodal point during specification of the muscle cell lineage. Science 251(4995):761-766; 1991.

90. Weiss, S.; Dunne, C.; Hewson, J.; Wohl, C.; Wheatley, M.; Peterson, A. C.; Reynolds, B. A. Multipotent CNS stem cells are present in the adult mammalian spinal cord and ventricular neuroaxis. J. Neurosci. 16(23):7599-7609; 1996.

91. Yaffe, D.; Saxel, O. Serial passaging and differentiation of myogenic cells isolated from dystrophic mouse muscle. Nature 270(5639):725-727; 1977.

92. Yoon, K.; Nery, S.; Rutlin, M. L.; Radtke, F.; Fishell, G.; Gaiano, N. Fibroblast growth factor receptor signaling promotes radial glial identity and interacts with Notch1 signaling in telencephalic progenitors. J. Neurosci. 24(43): 9497-9506; 2004

93. Zhang, X.; Klueber, K. M.; Guo, Z.; Lu, C.; Roisen, F. J. Adult human olfactory neural progenitors cultured in defined medium. Exp. Neurol. 186(2):112-123; 2004.

94. Zhu, A. J.; Haase, I.; Watt, F. M. Signaling via beta1 integrins and mitogen-activated protein kinase determines human epidermal stem cell fate in vitro. Proc. Natl. Acad. Sci. USA 96(12):6728-6733; 1999. 
